\title{
Addressing the SDGs in sustainability reports: The relationship with institutional
} factors

\author{
Rosati, Francesco; Faria, Lourenco
}

Published in:

Journal of Cleaner Production

Link to article, DOI:

10.1016/j.jclepro.2018.12.107

Publication date:

2019

Document Version

Peer reviewed version

Link back to DTU Orbit

Citation (APA):

Rosati, F., \& Faria, L. (2019). Addressing the SDGs in sustainability reports: The relationship with institutional factors. Journal of Cleaner Production, 215, 1312-1326. https://doi.org/10.1016/j.jclepro.2018.12.107

\section{General rights}

Copyright and moral rights for the publications made accessible in the public portal are retained by the authors and/or other copyright owners and it is a condition of accessing publications that users recognise and abide by the legal requirements associated with these rights.

- Users may download and print one copy of any publication from the public portal for the purpose of private study or research.

- You may not further distribute the material or use it for any profit-making activity or commercial gain

- You may freely distribute the URL identifying the publication in the public portal

If you believe that this document breaches copyright please contact us providing details, and we will remove access to the work immediately and investigate your claim 


\title{
Addressing the SDGs in sustainability reports: The relationship with institutional factors
}

\author{
Francesco Rosati (frro@dtu.dk) ${ }^{1}$ \\ Department of Management Engineering, Technical University of Denmark, Kgs. Lyngby, \\ Denmark
}

\section{Lourenço Galvão Diniz Faria (loufa@dtu.dk)}

Department of Management Engineering, Technical University of Denmark, Kgs. Lyngby, Denmark

\begin{abstract}
Organizations worldwide can play a significant role in the advancement of the Sustainable Development Agenda. However, there might be various factors influencing organizations' decisions to address sustainability issues. This study aims to conduct an analysis of the country-level institutional factors related to the decision to address the Sustainable Development Goals in sustainability reports. The research is undertaken by considering 27 institutional factors belonging to six different national institutional systems, and it relies on data from 2,413 sustainability reports published by organizations located in 90 different countries. The results show that organizations reporting on the Sustainable Development Goals are more likely to be located in countries with higher levels of climate change vulnerability, national corporate social responsibility, company spending on tertiary education, indulgence and individualism, and lower levels of market coordination, employment protection, power distance and long-term orientation. The study contributes to the literature on sustainable development and sustainability reporting by investigating the institutional factors related to addressing the Sustainable Development Goals in sustainability reports. The study can be useful for managers, investors and decision makers to develop country-specific strategies, investment plans, and policies to support organizations in contributing to the Sustainable Development Goals.
\end{abstract}

\footnotetext{
1 Corresponding Author: Francesco Rosati (rro@dtu.dk), Department of Management Engineering, Technical University of Denmark, Centrifugevej, Building 372, room 207, DK-2800 Lyngby, Tel: +45 45256021.
} 


\section{Keywords}

Sustainable Development Goals; Sustainability reporting; SDG reporting; Institutional factors; Country-level analysis.

\section{Introduction}

In 2015, the General Assembly of the United Nations adopted the 2030 Agenda for Sustainable Development as a "plan of action for people, planet and prosperity", which "seeks to strengthen universal peace in larger freedom” (United Nations General Assembly, 2015, p.1). As part of the 2030 Agenda for Sustainable Development, the United Nations announced 17 Sustainable Development Goals (SDGs) and 169 targets, which, according to the UN Secretary-General Ban Kimoon, represent not only a vision shared by all humanity but also a concrete to-do list and blueprint for success for all human beings. The SDGs range from ending world poverty to undertaking urgent action to combat climate change and its impacts by 2030, balancing economic, social and environmental development.

Organizations worldwide can play a significant role for the advancement of the Sustainable Development Agenda, by integrating SDGs into their strategies and operations and providing new solutions to global sustainable development challenges (United Nations Global Compact, 2018a). Conversely, the need for new solutions to address global challenges can generate new opportunities for organizations to innovate their value propositions, reach new customer segments, collaborate with new partners, and develop new and more sustainable business models (Bocken et al., 2014; Boons and Lüdeke-Freund, 2013; Geissdoerfer et al., 2018; Morioka et al., 2017).

However, there might be various external and internal factors influencing organizations’ decisions to address sustainability issues and report on their sustainability commitments (Hahn and Kühnen, 2013). Although many scholars have analysed the influence of both internal and external factors on sustainability reporting, there is no agreement regarding which dimension is the dominant; therefore, it is likely that both dimensions can play a significant role (Liu and Anbumozhi, 2009). This study particularly contributes to the understanding of the relationship between an organization's willingness to address the SDGs in its sustainability report and various external institutional factors related to the organization's country of origin. Investigating these factors could have important implications for 
managers, investors and decision makers (Halkos and Skouloudis, 2016; Jensen and Berg, 2012) who are responsible for designing country-specific strategies, investments, and policies to support SDG reporting and implementation (Global Reporting Initiative, 2016a; United Nations Global Compact, 2018b, 2018c). Investigating these factors might also be relevant for other stakeholders, such as citizens, societal leaders, educators, scholars, environmental authorities, non-profit organizations and international organizations committed to the achievement of the SDGs (Giannetti et al., 2018).

This research is conducted by considering 27 institutional factors belonging to six different institutional systems, and it relies on data from 2,413 sustainability reports published by organizations located in 90 different countries.

The following section reviews and discusses the literature on corporate sustainability, the SDGs and SDG reporting, and it illustrates the research hypotheses of the authors on the relationship between SDG reporting and various country-level institutional factors. Section 3 presents the research methods and dataset, and Section 4 provides the results of the study. The final sections present a summary of the study discussions (Section 5), limitations and recommendations for future research (Section 6), and conclusions (Section 7).

\section{Literature Review}

\subsection{Corporate Sustainability and the SDGs}

Corporate sustainability has become vital for organizations’ long-term success (Eccles et al., 2012; Ortiz-de-Mandojana and Bansal, 2016), and it has been increasingly studied in the academic literature in recent decades (Linnenluecke et al., 2009; Russell et al., 2007). Corporate sustainability generally refers to the integration of the triple bottom line of financial profitability, environmental protection and social responsibility into organizations' core purpose and activities (Elkington, 1998; Lo, 2010; Schaltegger et al., 2013). The concept is thus closely related to the concepts of sustainable development (Dyllick and Hockerts, 2002; Lozano, 2015, 2011) and corporate social responsibility (CSR) (see Montiel, 2008), for which it is sometimes considered a synonym (for a review on this subject see Ebner and Baumgartner, 2006), an outgrowth (e.g., Christofi et al., 2012), or even an evolution (e.g., Taylor, 2013). In this regard, Dyllick and Hockerts (2002, p. 131), building upon the definition of sustainable development (see World Commission on Environment and Development, 1987), defined corporate sustainability as “meeting the needs of a firm's direct and indirect stakeholders (such as shareholders, employees, clients, pressure groups, communities, etc.), without compromising its ability to meet the needs of future stakeholders as well”. 
In this study, the authors follow Dyllick and Hockerts' definition to apply the concept of sustainable development at the business level and build upon the considerations of current and future stakeholder needs as central elements of corporate sustainability. A shared expression of stakeholder needs is currently represented at the global level by the 17 SDGs and the associated 169 targets announced by the United Nations General Assembly (2015). As stated by the United Nations General Assembly (2015, p. 3), “[t]he goals and targets are the result of over two years of intensive public consultation and engagement with civil society and other stakeholders around the world, which paid particular attention to the voices of the poorest and most vulnerable”. Thus, the SDGs aim to inspire the integration of sustainability into organizations operating in the most various geographical areas worldwide, addressing current and future stakeholder needs and contributing to the achievement of sustainable development for society at large (United Nations Global Compact, 2018b).

SDGs have already been studied within the corporate sustainability literature in relation to their role as a reference framework for assessing corporate sustainability (Topple et al., 2017), improving sustainability engagement (Schönherr et al., 2017), providing investment opportunities (Schramade, 2017), and designing sustainable business models (Morioka et al., 2018, 2017). The corporate sustainability literature also includes studies of the potential role of multinational enterprises (Kolk et al., 2017) and advertising and marketing companies (Jones et al., 2018) in the achievement of the sustainable development agenda and on the relationship existing between SDG attainment and organizational legitimacy (Donoher, 2017). Although many goals might still present issues regarding their performance measurements, operationalization and interlinkages across sectors, societal actors and countries (Hák et al., 2016; Stafford-Smith et al., 2017), the SDGs have already been linked to concepts such as industrial ecology and strategic management to support organizations to positively contribute to the SDGs while building competitive advantage (Sullivan et al., 2018).

Recently, three special issues have focused on the contribution of business to achieving the SDGs - one was published in Transnational Corporations (Witte and Dilyard, 2017), and two will be published in Academy of Management Discoveries (Howard-Grenville et al., 2017) and Corporate Governance (Pedersen et al., 2018). Moreover, academic conferences worldwide are increasingly focusing or including tracks on SDGs (e.g., the $16^{\text {th }}$ Academy of Business in Society (ABIS) Annual Colloquium, the 2017 Annual Meeting of the Academy of Management, the $24^{\text {th }}$ International Sustainable Development Research Society Conference).

The academic debate within the field of corporate sustainability is thus increasingly providing research contributions aimed at supporting and driving the incorporation of SDGs into business.

\subsection{Sustainability and SDG reporting}


In this subsection, the authors present the emerging literature on SDG reporting and discuss the potential role of sustainability reporting in the advancement of the SDGs.

Sustainability reporting can be defined as the practice of reporting publicly on an organization's economic, environmental and/or social sustainability impacts (see also Global Reporting Initiative, 2016a). SDG reporting is thus defined in this study as the practice of reporting publicly on how an organization addresses the SDGs (see Global Reporting Initiative, 2018a; United Nations Global Compact, 2018c).

The United Nations Conference on Trade and Development report, reviewed by Gugler (2015), recognized that "[s]ustainability reporting initiatives are important because they help to align capital market signals with sustainable development and thereby to mobilize responsible investment in the SDGs” (United Nations Conference on Trade and Development, 2014, p. 162). Sustainability reporting can also have significant influences on corporate actions and strategies (see Adams, 2017) and, consequently, trigger the integration of SDGs into businesses. In addition, the lack of transparency and accountability can hinder progress towards the SDGs (Agarchand and Laishram, 2017; Anasi et al., 2018). Coherently, Bebbington and Unerman (2018) recently proposed an accounting research agenda for the SDGs by emphasizing the enabling role of accounting scholars and technologies for the implementation and achievement of the SDGs (see also Bowen et al., 2017).

According to these studies, sustainability reporting can thus be seen as an enabler of SDG actions, investments and strategies (see also Global Reporting Initiative, 2016), as already acknowledged by two leading global institutions on sustainable development and sustainability reporting - the United Nations Global Compact (UNGC) and the Global Reporting Initiative (GRI) - which recently established a joint initiative: Reporting on the SDGs (Global Reporting Initiative, 2018a; United Nations Global Compact, 2018c). The aim of the initiative is "to enable businesses to incorporate SDG reporting into their existing processes, empowering them to act and make the achievements of the SDGs a reality” (United Nations Global Compact, 2018c). Accordingly, the literature on corporate sustainability has shown that sustainability reporting can be an important driver of an organization's sustainability orientation (Lozano, 2015; Siebenhüner and Arnold, 2007). Sustainability reports can thus lend themselves very well to measuring, understanding, driving, and communicating organization SDG efforts, setting internal goals and managing the transition towards more sustainable development (Global Reporting Initiative, 2018b).

At the same time, the SDGs can also play an important role in the advancement of sustainability reporting. Indeed, according to Bebbington and Unerman (2018) and Stafford-Smith et al. (2017), the SDGs have the potential to inform and advance research and practice on sustainability accounting and reporting, as they represent a sufficiently radical, coherent, and generally accepted definition of sustainable development (Bebbington et al., 2017) and a compelling call for sustainability action 
(Shoaf et al., 2018; Thorlakson et al., 2018; Verdolini et al., 2017). Coherently, Garcia-Torres et al. (2017) embedded the SDGs as a key element of the "Fast-Fashion Sustainability Scorecard" - an action-oriented disclosure framework aimed at fostering sustainable value creation in the fast-fashion industry.

However, Schramade (2017) empirically found that only a minority of companies currently mention the SDGs in their reports ${ }^{2}$ and concluded that one of the key challenge in terms of SDG and implementation is linking them with specific incentives that might influence the choice to invest in the SDGs. Accordingly, Rosati and Faria (2018) found that only 67 out of the 408 organizations included in their sample (16\%) addressed the SDGs in the sustainability reports published in 2016. Rosati and Faria (2018) also investigated the relationship between adoption of SDG reporting and a series of internal organizational factors, and concluded that SDG reporting is related to a larger size, a higher level of intangible assets, a higher commitment to sustainability frameworks and external assurance, a higher share of female directors, and a younger board of directors. However, as emphasized by Biermann et al. (2017), the challenging implementation of the SDGs might also be influenced by the extent to which countries concretely formalize their commitments to the SDGs and by their ability to turn global challenges into national issues. Coherently, as discussed in the next subsection, the authors argue that the implementation of the SDGs might benefit from particular institutional conditions that provide incentives for SDG investment, implementation and reporting.

\subsection{Institutional factors related to SDG reporting}

Scholars have long pointed out that the country-specific institutional environment can affect the behaviour of organizations by defining the "rules of the game" that affect the efficiency and legitimacy of organizational structures (Delmas and Toffel, 2008). Specifically regarding sustainability, the organization's country (or region) of origin has been found to have an effect on the adoption (Buhr and Freedman, 2001; Jensen and Berg, 2012), the extent (Chen and Bouvain, 2009; Fortanier et al., 2011; Hahn and Kühnen, 2013; Prado-Lorenzo et al., 2009) and the quality of sustainability reporting (Vormedal and Ruud, 2009). According to previous studies of sustainability reporting, the country of origin can influence sustainability reporting, mainly because of differences in institutional characteristics, such as political and legal systems, economics and finance, sociocultural norms and education and labour systems (see also Hahn and Kühnen, 2013; Jensen and Berg, 2012). In this regard, Jensen and Berg (2012) explored a sample of 309 worldwide companies

\footnotetext{
${ }^{2}$ In particular, through an internal NN Investment Partners' research, Schramade (2017, p. 88) found that " $40 \%$ of the Dow 30, 28\% of the Eurostoxx 50, and 28\% of the largest 30 companies in the Nikkei 225 mentioned the SDGs in their 2015 reporting”.
} 
to study the effect of several country-level determinants on the publication of integrated reports (The International Integrated Reporting Council, 2013). Jensen and Berg (2012, p. 299) concluded that "investor and employment protection laws, the intensity of market coordination and ownership concentration, the level of economic, environmental and social development, the degree of national corporate responsibility and the value system of the country of origin proved to be relevant" determinants.

In this subsection, the authors build upon the previous findings in the corporate sustainability literature to derive various research hypotheses on the relationship between different institutional conditions and SDG reporting. The formulated research hypotheses are divided in six groups, which represent six different institutional systems that can be related to SDG reporting, such as country politics and law, economics and finance, society and culture, technology and innovation, education and labour, and sustainability (Table 1). Four of the six institutional systems (i.e., politics and law, economics and finance, society and culture, education and labour) are defined in accordance with previous studies of national institutional frameworks (e.g., Jensen and Berg, 2012; Matten and Moon, 2008), mainly inspired by institutional theory. Moreover, the institutional framework presented in this study extend the previous research by including two additional institutional systems - country technology and innovation and country sustainability - which have already been found to be related to organizations’ sustainability performance and reporting (Halkos and Skouloudis, 2018; Jensen and Berg, 2012; Seitz, 2016).

Insert Table 1 about here

\subsubsection{Politics and law}

Political and legal systems can enormously influence organizations’ strategies and activities and consequently their sustainability goals and performance. However, the extent of this influence might depend on the type of legal system used by a country (i.e., civil vs. common law countries) (see also Jensen and Berg, 2012; Kolk and Perego, 2010).

Civil law countries are characterized by a relatively strong political influence on economic activities and accounting standards (e.g., Kolk and Perego, 2010; Zhao and Millet-Reyes, 2007). Organizations are expected to act responsibly and transparently within society and for a broad group of societal stakeholders (Jensen and Berg, 2012; Kolk and Perego, 2010; Legendre and Coderre, 2013). 
Countries with a common law legal system present, in contrast a weaker political influence on economic activities, and organizations are more focused on shareholders' needs than stakeholders' needs (Jensen and Berg, 2012; Kolk and Perego, 2010; La Porta et al., 1998; Legendre and Coderre, 2013). Therefore, the authors hypothesize the following:

$H_{1 a}$ SDG reporting organizations are more likely to be located in civil law countries.

To analyse the relationship between SDG reporting and politics and law in greater detail, the authors also analyse the social and environmental aspects of legal protection and policy.

In particular, the authors assume that, in countries where social (such as employment conditions) and environmental (such as reduction of environmental impacts) needs are highly valued, the political and legal systems tend to strongly protect such needs (such as employment protection and environmental policy stringency) (Jackson and Apostolakou, 2010; Jensen and Berg, 2012). Therefore, in countries where social and environmental needs are highly valued, organizations might perceive stronger pressure from both the public and the legal system to care about social and environmental issues, which might reflect on their sustainability performance (Aguinis and Glavas, 2012; Horbach, 2008; Porter and van der Linde, 1995) and their willingness to provide sustainability reporting (such as SDG reporting). Thus, the authors hypothesize the following:

$H_{1 b}$ SDG reporting organizations are more likely to be located in countries with stronger employment protection laws.

$H_{1 c}$ SDG reporting organizations are more likely to be located in countries with higher levels of environmental policy stringency.

\subsubsection{Economics and finance}

Following Jensen and Berg (2012) and Fasan et al. (2016), the authors hereby assume that sustainability reporting practices can be related to the economic development of an organization's country of origin. Indeed, countries with higher levels of economic development are characterized by more advanced social and institutional capacity for sustainability (Husted, 2005). Consequently, organizations located in these countries might have more resources to dedicate to sustainability (Baughn et al., 2007) and might perceive more public pressure to report on sustainability issues (Ali et al., 2017). Accordingly, the authors hypothesize that this fact affects SDG reporting: 
$H_{2 a}$ SDG reporting organizations are more likely to be located in countries with higher levels of economic development.

Furthermore, the authors hypothesize that economic freedom can also play a role in terms of sustainability reporting. Indeed, previous studies have found that the economic freedom of a country, when interacting with other factors (such as a strong national sustainability culture), can have a positive influence on the sustainability performance of the country (Roy and Goll, 2014). Economic freedom thus might be a factor enabling increases in the level of sustainability reporting (as suggested by Fasan et al., 2016; Jensen and Berg, 2012). This might occur because economic freedom can reduce the effects of corruption and encourage businesses to take responsibility for their impact on social welfare (Baughn et al., 2007; Nwabuzor, 2005). Thus, the authors hypothesize the following:

$H_{2 b}$ SDG reporting organizations are more likely to be located in countries with higher levels of economic freedom.

Concerning financial systems, the authors can distinguish between market-based and bank-based systems. In market-based systems, market coordination is high, and companies financially depend on a large number of stakeholders (see also Jensen and Berg, 2012). In these systems, stakeholders analyse companies' information independently and base their support and investment decisions on such analyses. Companies are thus highly motivated to openly disclose their performance (including sustainability performance) to foster stakeholder engagement and support.

In bank-based systems, however, market coordination is lower, and banks act as the main financial providers and intermediaries between investors and companies. Given the high influence that banks have on companies, they have direct access to companies' information and can consequently monitor companies’ performance (Duran and Bajo, 2014). In these systems, companies are thus less motivated to report their performance to the public (Ali and Hwang, 2000).

Therefore, the authors hypothesize the following:

$\mathrm{H}_{2 c}$ SDG reporting organizations are more likely to be located in countries with higher degrees of market coordination.

Finally, Jensen and Berg (2012) found a significant impact of the degree of ownership concentration in a company on the form of sustainability reporting (traditional versus integrated reporting). In particular, they found that more dispersed corporate ownership is moderately related to 
integrated reporting. Coherently, previous research has found that dominant owners are neither dependent on published information nor interested in publishing detailed and clear company information (e.g., Fan and Wong, 2002) since, in their view, doing so can lead to loose competitive advantage.

The authors argue that ownership concentration can also affect SDG reporting and hypothesize the following:

$H_{2 d}$ SDG reporting organizations are more likely to be located in countries with lower degrees of ownership concentration.

\subsubsection{Society and culture}

A country's social development can play an important role in the other two dimensions of sustainable development (i.e., economic development and environmental protection) (Salim, 2015). In this section, the authors discuss two different aspects related to social development: human development and civic engagement.

Human development has been found to be positively related to economic growth (Albassam, 2013), low corruption (Sims et al., 2012), and women’s labour force participation rate (Naidu, 2016). Indeed, according to the United Nations Development Programme (2016, p. iv), "[t]he human development approach and the 2030 Agenda can be mutually reinforcing by contributing to the narrative of each other, by exploring how human development and Sustainable Development Goal indicators can complement each other and by being a forceful advocacy platform for each other”. Therefore, the authors hypothesize the following:

$H_{3 a}$ SDG reporting organizations are more likely to be located in countries with higher levels of human development.

Civic engagement has not only been found to be related to sustainability (Goldberger, 2011; Grant et al., 2004; Shutkin, 2003), but it is even considered an integral part of what it means to be sustainable (Portney, 2005). Coherently, Halkos and Skouloudis (2016) found that civic engagement was a very significant factor influencing CSR penetration at the national level. Thus, the authors argue that civic engagement can also play a role in terms of SDG reporting. Accordingly, the authors hypothesize the following: 
$H_{3 b}$ SDG reporting organizations are more likely to be located in countries with stronger civic engagement.

Hofstede et al. (2010, p. 6) defined culture as "the collective programming of the mind which distinguishes the members of one group or category of people from another”, and national culture as "the collective programming of the mind acquired by growing up in a particular country" (Hofstede et al., 2010, p. 520). In their work, Hofstede et al. (2010) identified six dimensions of national culture: masculinity, individualism, power distance, uncertainty avoidance, long-term orientation and indulgence versus restraint. Hofstede et al.'s national culture dimensions have been widely used in various academic fields, including CSR (Fernandez-Feijoo et al., 2012; Williams and Zinkin, 2008) and sustainable development (Vachon, 2010). For the purpose of this paper, Hofstede et al.'s (2010) six cultural dimensions are examined to detect the relationship between a country's culture and organizations’ SDG reporting.

Concerning masculinity, Hofstede et al. (2010, p. 140) stated that “[a] society is called masculine when emotional gender roles are clearly distinct: men are supposed to be assertive, tough, and focused on material success, whereas women are supposed to be more modest, tender, and concerned with the quality of life. A society is called feminine when emotional gender roles overlap: both men and women are supposed to be modest, tender, and concerned with the quality of life”. A masculine society is thus related to pursuing economic success, while a feminine society is related to caring for society members (Fernandez-Feijoo et al., 2012; Orij, 2010; Park et al., 2007; Vachon, 2010; Williams and Zinkin, 2008). Accordingly, Ringov and Zollo (2007) found that organizations based in more masculine countries show lower levels of social and environmental performance. Thus, building on these studies, the authors hypothesize the following:

$H_{3 c}$ SDG reporting organizations are more likely to be located in less masculine countries.

According to Hofstede et al. (2010, p. 92) “[i]ndividualism pertains to societies in which the ties between individuals are loose: everyone is expected to look after him- or herself and his or her immediate family. Collectivism as its opposite pertains to societies in which people from birth onward are integrated into strong, cohesive in-groups, which throughout people's lifetime continue to protect them in exchange for unquestioning loyalty”.

Thus, while the members of an individualistic society look after themselves and their immediate families, in a collectivistic society, members identify themselves with a group and act for the benefit of it (Fernandez-Feijoo et al., 2012; Park et al., 2007; Williams and Zinkin, 2008). Therefore, in more individualistic cultures, members are less inclined to show commitments to society, including issues 
related to public good and sustainability (García-Sánchez et al., 2013). Accordingly, García-Sánchez et al. (2013), analysing a sample of 1,590 companies located in 20 different countries, found that companies located in countries with higher levels of individualism are less likely to engage in integrated reporting. Therefore, the authors hypothesize that:

$H_{3 d}$ SDG reporting organizations are more likely to be located in less individualistic countries.

The third cultural dimension included in this study is power distance. Hofstede (2001, p. XIX) defined power distance as "the extent to which the less powerful members of organizations and institutions accept and expect that power is distributed unequally". Therefore, power distance measures "the degree of human inequality that underlies the functioning of each particular society" (Hofstede, 2001, p. xix).

Previous studies have argued that organizations located in countries scoring higher on power distance typically present heavier hierarchical structures (Vachon, 2010), less transparency (PahlWostl et al., 2008), less meritocratic systems and stronger degrees of favouritism and loyalty to authority (Husted, 2005). As a consequence, members of societies scoring higher on power distance should be more prone to accepting unsustainable organizational practices, including poor working conditions and polluted environments (Vachon, 2010). Additionally, they should also be less inclined to openly discuss sustainability initiatives and adopt a stakeholder-oriented approach (Ringov and Zollo, 2007). Accordingly, previous studies have found that countries scoring higher on power distance present lower social and institutional capacity for environmental sustainability (Husted, 2005), lower weighted gross domestic product per capita balanced with environmental sustainability (Cox et al., 2011), and lower scores on the Environmental Sustainability Index developed by the World Economic Forum (Park et al., 2007). Similarly, Ringov and Zollo (2007), analysing a sample of 463 organizations from 23 North American, European and Asian countries, found that a country’s score on power distance has a significant, negative effect on corporate social and environmental performance. Therefore, the authors hypothesize the following:

$H_{3 e}$ SDG reporting organizations are more likely to be located in countries with lower levels of power distance.

The fourth cultural dimension considered here is uncertainty avoidance. Hofstede (2001, p. xix) described uncertainty avoidance as "the extent to which a culture programs its members to feel either uncomfortable or comfortable in unstructured situations”. For "unstructured situations”, Hofstede (2001, p. xx) referred to situations that are "novel, unknown, surprising, different form usual”. 
Organizations located in uncertainty avoiding countries might thus encounter more difficulties in adapting to novel sustainability demands and practices (Ringov and Zollo, 2007). Accordingly, previous studies have hypothesized a negative effect of uncertainty avoidance on the social and institutional capacity for environmental sustainability (Husted, 2005), corporate social and environmental performance (Ringov and Zollo, 2007), and corporate sustainable development practices (Vachon, 2010) but without finding empirical evidence justifying their hypotheses.

In this study, the authors argue that SDG reporting, as a very novel and challenging practice for organizations worldwide (Schramade, 2017), will be more difficult to implement in uncertainty avoiding societies. Thus, the authors hypothesize the following:

$H_{3 f}$ SDG reporting organizations are more likely to be located in countries with lower levels of uncertainty avoidance.

The fifth cultural dimension considered in this study is long-term orientation. According to Hofstede et al. (2010, p. 239), "long-term orientation stands for the fostering of virtues oriented towards future rewards - in particular, perseverance and thrift. Its opposite pole, short-term orientation, stands for the fostering of virtues related to the past and present - in particular, respect for tradition, preservation of 'face,' and fulfilling social obligations”.

Past studies have hypothesized that long-term orientation (LTO) is likely to be positively related to a stakeholder perspective, and thus to corporate social disclosure (Orij, 2010) and integrated reporting (García-Sánchez et al., 2013). Accordingly, the authors hypothesize that:

$H_{3 g}$ SDG reporting organizations are more likely to be located in more long-term-oriented countries.

Finally, the last cultural dimension included here is indulgence versus restraint. According to Hofstede (2001, p. 281) “[i]ndulgence stands for a tendency to allow relatively free gratification of basic and natural human desires related to enjoying life and having fun. Its opposite pole, restraint, reflects a conviction that such gratification needs to be curbed and regulated by strict social norms".

Thus, an indulgent society highly values the personal life control and freedom of behaviour, speech and thought of its members (Hofstede et al., 2010). Consequently, members of indulgent societies might have a greater likelihood of freely demanding that organizations address specific sustainability issues and publicly report on them. Coherently, Halkos and Skouloudis (2017) found a positive relationship between a country score on indulgence and national CSR penetration (measured according to the National CSR Index proposed by Skouloudis et al., 2016). However, Gallego- 
Álvarez and Ortas (2017) did not observe any significant effect of indulgence on corporate environmental sustainability reporting (CESR) for most of the companies considered in their sample. They found instead that indulgence has a negative influence on CESR for those companies showing the highest commitment to CESR. In this study, following the reasoning outlined above, the authors hypothesize that:

$H_{3 h}$ SDG reporting organizations are more likely to be located in indulgent countries.

\subsubsection{Technology and innovation}

In this study, the authors assume that organizations based in countries with higher levels of innovation and technological knowledge production have more resources (in terms of knowledge bases and capabilities) that can be used to adopt and promote sustainability management instruments (Jensen and Berg, 2012), such as those required to comply with the SDGs. Previous studies have shown that research and development (R\&D) efforts can be positively correlated with CSR (see also Halkos and Skouloudis, 2018), since the implementation of sustainable production systems often requires investments in the research and development of new technologies that consider sustainability issues (Bansal, 2005; McWilliams and Siegel, 2001). Moreover, countries that possess superior innovation performance levels are expected to be at the forefront of the technological race, which has been increasingly shifting towards the development of sustainability innovations for many sectors (OECD, 2011). Therefore, a country's common innovation infrastructure and its innovation intensity are related to the flow of innovative technologies over time (Furman et al., 2002), increasingly including the production of sustainable technologies (Mathur and Berwa, 2017). This flow of technologies might encourage organizations in these national environments to commit to the SDGs earlier and include them in their sustainability reports. Accordingly, the authors selected a number of variables to represent the technological knowledge and innovative capacity of the countries and formulated the following hypotheses:

$H_{4 a}$ SDG reporting organizations are more likely to be located in countries with higher levels of company spending on $R \& D$.

$H_{4 b}$ SDG reporting organizations are more likely to be located in countries with higher levels of university-industry collaboration in $R \& D$. 
$H_{4 c}$ SDG reporting organizations are more likely to be located in countries with higher levels of capacity for innovation.

$H_{4 d}$ SDG reporting organizations are more likely to be located in countries with higher levels of technological knowledge.

\subsubsection{Education and labour}

The literature on CSR and business ethics has shown that education can influence attitudes, perceptions and expectations (Dellaportas, 2006; Elias, 2004; Luthar et al., 1997; Rosati et al., 2018). In particular, Elias (2004) and Luthar et al. (1997) found that a business ethics education can positively influence students' attitudes, awareness, and expectations in terms of CSR and business ethics. Previous studies have also found that, on average, individuals with higher levels of education show a greater CSR orientation (Kelley et al., 1990) and have higher CSR expectations (Calabrese et al., 2016) and more elaborate CSR perceptions (Quazi, 2003). This finding seems to hold true at the country level, with higher education levels in a country being positively related to national environmental sustainability (Park et al., 2007). Similarly, the authors hypothesize a positive relationship between education and orientation towards the SDGs and, consequently, SDG reporting:

$H_{5 a}$ SDG reporting organizations are more likely to be located in countries with higher levels of education.

Following Jensen and Berg (2012), the authors also assume that organizations with higher levels of investments in tertiary education exhibit stronger interest in new research advancements and academic knowledge and will thus be able to discover and adopt new management frameworks (including sustainability reporting frameworks) more rapidly. Building on this idea, the authors hypothesize that:

$H_{5 b}$ SDG reporting organizations are more likely to be located in countries with higher levels of company spending on tertiary education.

Finally, concerning the labour system, the authors assume that a high density of trade unions in a country is positively related to employee involvement in decision making (Jensen and Berg, 2012) and socio-political progress (De Geer et al., 2010). The authors then argue that socio-political 
progress and employee involvement might be related to greater organization sensitivity to the SDGs. Based on this concept, the authors develop the following hypothesis:

$H_{5 c}$ SDG reporting organizations are more likely to be located in countries with higher density of trade unions.

\subsubsection{Sustainability}

In this section, according to previous studies (Jensen and Berg, 2012; Kolk and Perego, 2010; Sotorrío and Sánchez, 2010), the authors argue that the level of corporate responsibility, environmental performance and, more generally, sustainable development of a country can impact organizations' sustainability performance. This relationship might be due to the influence of specific national regulations or cultural factors on companies' sustainability practices. Based on these considerations, the authors assume that the level of corporate responsibility, environmental performance and sustainable development can also influence SDG reporting. Therefore, the authors develop the following three research hypotheses:

$H_{6 a}$ SDG reporting organizations are more likely to be located in countries with higher levels of national corporate responsibility.

$H_{6 b}$ SDG reporting organizations are more likely to be located in countries with higher levels of environmental performance.

$H_{6 c}$ SDG reporting organizations are more likely to be located in countries with higher levels of sustainable development.

Finally, the authors assume that organizations located in countries that are more vulnerable - or less ready to adapt - to climate change experience greater political and social pressure to act more sustainably and are thus more likely to report on SDGs (Hassan and Ibrahim, 2012). Therefore, the authors hypothesize the following:

$H_{6 d}$ SDG reporting organizations are more likely to be located in countries with lower levels of climate adaptation readiness. 
$H_{6 e}$ SDG reporting organizations are more likely to be located in countries with higher levels of climate vulnerability.

\section{Methods}

\subsection{Data}

The sample of this study consists of the organizations listed in the GRI database (Global Reporting Initiative, 2018c) that satisfy the following three conditions:

1. The organization published a sustainability report in 2016;

2. The organization sustainability report was written in accordance with GRI standards (GRI G4 Guidelines or other GRI Standards); and

3. GRI provided information about whether the organization sustainability report addressed the SDGs or not.

The authors used 2016 as the reference year for the analysis to identify the fastest adopters of SDGs, which were announced in September 2015. The authors selected only those organizations following GRI standards because GRI gathered information about SDG reporting only for those reports written in accordance with GRI standards. The third condition was included to select only those organizations for which GRI provided information about SDG reporting.

As a result, the authors obtained valid data from 2,413 organizations located in 90 different countries.

\subsection{Measures}

The dependent variable is a Boolean variable that tracks whether or not organizations have addressed the SDGs in their sustainability reports, as shown in the GRI database.

The independent variables were acquired from different sources, as shown in Table 1. For all of the independent variables, in accordance with the publishing year of the sustainability report, the authors used data for 2016, if available. Otherwise, the authors used the most recent data. Table A in the Appendix shows the variables considered in the study and, for each variable, the data corresponding to the 90 countries included in the dataset.

Concerning the political and legal system, according to the research hypotheses, the authors collected data on three variables: legal system (PL-COCI); employee protection (PL-EMPR); and environmental policy stringency (PL-EPSI). The Boolean variable PL-COCI expresses a country’s 
legal system, differentiating between common law and civil law countries. The differentiation follows the classification provided by La Porta et al. (1998) and used in previous studies in the corporate sustainability literature (e.g., Jensen and Berg, 2012; Kolk and Perego, 2010). The level of employee protection within a country is expressed by PL-EMPR. To measure PL-EMPR, the authors used OECD's (2018a) data describing the level of employment protection within various OECD and nonOECD countries. In particular, the authors used the synthetic indicator of protection of permanent workers against individual and collective dismissals (expressed on a scale from 0 to 6 for least to most restrictions). PL-EPSI (environmental policy stringency) is measured by the OECD Environmental Policy Stringency Index, computed by OECD (2018b) and based on Botta and Koźluk (2014). The index is defined by OECD (2018b), as "the degree to which environmental policies put an explicit or implicit price on polluting or environmentally harmful behaviour”. The index ranges from 0 to 6, with 0 indicating non-stringency and 6 indicating the highest degree of stringency, and it is based on the level of stringency of 14 instruments of environmental policy, e.g., related to air and climate pollution.

Concerning the economic and financial system, the authors collected data on four variables: economic development (EF-GNI); economic freedom (EF-EFI); market coordination (EF-COOR); and ownership concentration (EF-OWNE). EF-GNI expresses the level of economic development of a country, and it is measured by the World Bank's (2018) per-capita GNI. EF-EFI describes the economic freedom of a country, and it is measured by the Economic Freedom Index, published by the Heritage Foundation (2018) and ranging from 0 to 100 for lowest to highest level of economic freedom. The degree of market coordination (EF-COOR) is computed by Hall and Gingerich (2004), who provided a coordination index that includes factors such as shareholder power, dispersion of control, size of stock market, level of wage coordination, labour turnover, and degree of wage coordination. The index ranges between 0 and 1 , with lower values indicating high importance of market coordination within the political economy of a country. Ownership concentration (EFOWNE) was measured according to La Porta et al. (1998), who provided, for 49 countries, a measure of ownership concentration based on the mean of the ownership by the three largest shareholders of the 10 largest nonfinancial domestic firms of a country.

Concerning the socio-cultural system, the authors collected data on seven variables: human development (SC-IHDI), civic engagement (SC-CEG), masculinity (SC-MAS), individualism (SCIND), long-term orientation (SC-LTO), power distance (SC-POW), uncertainty avoidance (SCUNC), and indulgence versus restraint (SC-IVR). The human development (SC-IHDI) of a country was measured using the Inequality-adjusted Human Development Index provided by the United Nations Development Programme (2016). This index quantifies the effects of inequality on human development, measured considering the life expectancy, education, and income per capita indicators 
of a country. The higher the score of a country is, the higher its combined levels of life expectancy, education, income, and equality are. A country's level of civic engagement (SC-CEG) was measured using the civic engagement and governance dimension of the education and social outcomes framework of OECD (2018c). In particular, the authors considered the percentage of adults reporting they believe that they have a say in government, i.e., people answering according to levels 4 and 5 for all educational levels on the civic engagement and governance dimension of the Survey of Adult Skills (OECD, 2018d). Data on country masculinity (SC-MAS), individualism (SC-IND), power distance (SC-POW) and uncertainty avoidance (SC-UNC) were obtained from Hofstede (2001). Data on country long-term orientation (SC-LTO) and indulgence versus restraint (SC-IVR) were obtained from Hofstede et al. (2010).

Data on technology and innovation were obtained from the World Economic Forum (2017a). In particular, data on company spending on R\&D (TI-RDEX) (World Economic Forum, 2017b), university-industry collaboration in R\&D (TI-UIRD) (World Economic Forum, 2017c), and capacity for innovation (TI-INCA) (World Economic Forum, 2017d) were based on the World Economic Forum's Executive Opinion Survey, expressed on a seven-point scale (1 to 7 for non-existent to high performance). Data on technological knowledge (TI-PAT) (World Economic Forum, 2017e) referred to the number of applications filed under the Patent Cooperation Treaty (WIPO, 2018) per million population of the country.

Concerning education and labour, the authors collected data on three variables: education, (ELEDI), company spending on tertiary education (EL-EDS), and density of trade unions (EL-TUD). Data on education (EL-EDI) were obtained from the Education Index provided by the United Nations Development Programme (2016), calculated, for various countries, using mean years of schooling and expected years of schooling. The higher the score of a country is, the higher its performance is in terms of education. Data on company spending on tertiary education (EL-EDS) were derived from OECD (2018e) (selecting the perspective “Other private entities”) and referred to private businesses and non-profit organization expenditures as percentages of total tertiary education spending. Data on density of trade unions (EL-TUD) were obtained from OECD (2018f) and corresponded to the ratio of wage and salary earners that are trade union members to the total number of wage and salary earners.

Concerning country sustainability, the authors collected data on five variables: national corporate responsibility (SU-NCSRI), environmental performance (SU-EPI), sustainable development (SUSDGI), climate adaptation readiness (SU-READY), and climate vulnerability (SU-VULN). National corporate responsibility was measured using the National CSR Index provided by Skouloudis et al. (2016), who revisited the previous index proposed by Gjølberg (2009). The index was constructed based on a series of 16 international CSR standards, rankings and initiatives, and describes the level 
of CSR conduct across different countries. The environmental performance of a country (SU-EPI) was measured using the Environmental Performance Index provided by Yale University (2018). This index varies between 0 and 100, with 0 indicating the highest environmental impact and thus the lowest environmental performance and 100 indicating the lowest environmental impact and thus the highest environmental performance. The sustainable development performance of a country (SUSDGI) was measured using the 2017 SDG Index, provided by Sachs et al. (2017). The SDG index condenses the 17 SDGs into a single index to provide an overall measure of the performance of a country in terms of SDG implementation. The higher the SDG Index score of a country is, the higher its performance is in terms of SDG implementation. The climate adaptation readiness (SU-READY) and vulnerability (SU-VULN) of a country were measured in accordance with the readiness and vulnerability dimensions of the ND-GAIN Country Index, provided by the University of Notre Dame (2018). In particular, the vulnerability dimension "measures a country's exposure, sensitivity and ability to adapt to the negative impact of climate change”, and the readiness dimension "measures a country's ability to leverage investments and convert them to adaptation actions” (University of Notre Dame, 2018). The higher a country's score is in terms of climate vulnerability, the more vulnerable the country is to climate change. Conversely, the higher a country's score is in terms of climate adaptation readiness, the more the country is judged to be able to adapt to climate change.

\section{Results}

In this study, the authors used two-tailed non-parametric tests to test for statistically significant differences between SDG reporting and non-SDG reporting organizations. In particular, for the nominal independent variable (PL-COCI), the authors conducted Pearson's chi-square test of independence and calculated phi to identify the strength of association existing between the country's legal system and SDG reporting (Table 2). For the ordinary-scaled independent variables, the authors conducted the Mann-Whitney U-test, which is the most appropriate nonparametric alternative to the independent t-test for the sample size (Table 3). In the interpretation of the test results, the authors applied a 5\% level of significance.

$H_{1 . a}$ proposed that SDG reporting organizations are more likely to be located in civil law countries. The results show that there is a very weak or no association between reporting on SDGs and being located in a common law country (Pearson's chi-square $=12.040 ; \mathrm{p}<0.01$; phi $=0.083$ ) (Table 2). Therefore, the authors can neither accept nor reject $H_{1 . a}$. 
$H_{1 b}$ postulated that SDG reporting organizations are more likely to be located in countries with stronger employment protection laws. The results of the Mann-Whitney U-test (Table 3) show that the contrary is true, with non-SDG reporting organizations scoring higher, on average, in terms of employment protection (PL-EMPR) than SDG reporting ones (respectively, 2.265 and 2.135). Thus, the authors reject this hypothesis.

In $H_{1 c}$, the authors hypothesized that SDG reporting organizations are more likely to be located in countries with higher levels of environmental policy stringency. The results show that the country Environmental Policy Stringency Index is higher, on average, for SDG reporting organizations than for non-SDG reporting ones. However, the difference is not significant ( $\mathrm{p}$-value $=0.062$ ). Therefore, the authors can neither accept nor reject $H_{1 c}$.

In $H_{2 a}$ and $H_{2 b}$, the authors postulated that SDG reporting organizations are more likely to be located in countries with higher levels of economic development (EF-GNI) and economic freedom (EF-EFI), respectively. However, the results do not show any significant difference between the two distributions (p-value ${ }_{\mathrm{EF}-\mathrm{GNI}}=0.956, \mathrm{p}$-value $\mathrm{EF}_{\mathrm{EFI}}=0.266$ ). Thus, the authors can neither accept nor reject $H_{2 a}$ and $H_{2 b}$.

$\mathrm{H}_{2 c}$ proposed that SDG reporting organizations are more likely to be located in countries with higher degrees of market coordination. The findings contradict the hypothesis and indicate that SDG reporting organizations are more likely to be located in countries with lower levels of market coordination (p-value EF-COOR $=0.022$ ). Therefore, the authors reject $H_{2 c}$.

In $H_{2 d}$, the authors hypothesized that SDG reporting organizations are more likely to be located in countries with lower degrees of ownership concentration (EF-OWNE). However, the results do not show any significant differences in terms of ownership concentration (p-value EF-OwnE $=0.186$ ). Thus, the authors can neither accept nor reject $H_{2 d}$.

$H_{3 a}$ and $H_{3 b}$ proposed that SDG reporting organizations are more likely to be located in countries with higher levels of human development (SC-IHDI) and stronger civic engagement (SC-CEG). However, the results do not show any significant difference (p-value sC-IHDI $=0.082$, $\mathrm{p}$-value SC-CEG $^{-}$ 0.752). Thus, the authors can neither accept nor reject $H_{3 a}$ and $H_{3 b}$.

Concerning country culture, in $H_{3 c}-H_{3 h}$, the authors postulated that SDG reporting organizations are more likely to be located in countries with lower levels of masculinity (SC-MAS), individualism (SC-IND), power distance (SC-POW) and uncertainty avoidance (SC-UNC), and higher levels of long-term orientation (SC-LTO) and indulgence (SC-IVR). The results do not show any significant difference in terms of country masculinity (p-value sc-MAs $=0.079)$ and uncertainty avoidance (p- 
value SC-UNC $=0.100)$. The authors found instead that SDG reporting organizations are more likely to be located in more individualistic and short-term-oriented countries (p-value sc-IND $<0.01$; p-value sC-LTo $<0.01$ ), contradicting $H_{3 d}$ and $H_{3 g}$, and in more egalitarian (p-value sc-pow $=0.033$ ) and indulgent countries (p-value sc-IVR $=0.001$ ), supporting $H_{3 e}$ and $H_{3 h}$.

Regarding technology and innovation, $H_{4 a}, H_{4 b}, H_{4 c}$, and $H_{4 d}$ proposed that SDG reporting organizations are more likely to be located in countries with higher levels of company spending on R\&D (TI-RDEX), higher levels of university-industry collaboration in R\&D (TI-UIRD), higher levels of capacity for innovation (TI-INCA), and higher levels of technological knowledge (TI-PAT). The results of this study do not show any significant difference in terms of country technology and innovation (p-value ${ }_{\text {TI-RDEX }}=0.774 ; \mathrm{p}$-value ${ }_{\text {TI-UIRD }}=0.821 ; \mathrm{p}$-value ${ }_{\text {TI-INCA }}=0.438 ; \mathrm{p}$-value TI-PAT $=$ 0.390). Therefore, the authors can neither accept nor reject $H_{4 a}, H_{4 b}, H_{4 c}$, and $H_{4 d}$.

$H_{5 a}, H_{5 b}$, and $H_{5 c}$ postulated that SDG reporting organizations are more likely to be located in countries with higher levels of education (EL-EDI), higher levels of company spending on tertiary education (EL-EDS), and higher density of trade unions (EL-TUD). The results do not show significant differences between SDG and non-SDG reporting organizations in terms of country education level and trade union density ( $\mathrm{p}$-value EL-EDI $=0.612 ; \mathrm{p}$-value EL-TUD $=0.800$ ). Therefore, the authors can neither accept nor reject $H_{5 a}$, and $H_{5 c}$. However, the findings seem to support $H_{5 b}$ (pvalue EL-EDS $=0.047$ ), showing that SDG reporting organizations are more likely to be based in countries with higher levels of company spending on tertiary education.

Concerning the relationship between country sustainability and SDG reporting, in $H_{6 a}$, $H_{6 b}$, and $H_{6 c}$, the authors hypothesized that SDG reporting organizations are more likely to be located in countries with higher levels of national corporate responsibility (SD-NCSRI), environmental performance (SD-EPI), and sustainable development (SD-SDGI). The results do not show significant differences in terms of environmental performance ( $\mathrm{p}$-value su-EPI $=0.745$ ) and sustainable development (p-value su-SDGI $=0.070$ ). Thus, the authors can neither accept nor reject $H_{6 b}$ and $H_{6 c}$. The results of the analysis show instead a significant difference in terms of national corporate responsibility, with SDG reporting organizations displaying higher average levels than non-reporting ones (p-value sU-NCSRI $=0.021)$.

Finally, focusing on the relationship between SDG reporting and climate change effects, $H_{6 d}$ and $H_{6 e}$ proposed that SDG reporting organizations are more likely to be located in countries with lower levels of climate adaptation readiness (SD-READY) and higher levels of climate vulnerability (SDVULN). The findings do not show significant results in terms of climate adaptation readiness (pvalue sU-READY $=0.685$ ). However, the analysis shows that SDG reporting organizations are more likely to be located in countries that are more vulnerable to climate change ( $p$-value su-vULN $=0.027$ ). 


\section{Discussion}

The results of this study did not support any of the hypotheses on the political and legal system. For one of the hypotheses $\left(H_{1 b}\right)$, the results even contradict the initial assumptions of the authors (similar to Jensen and Berg, 2012), showing that SDG reporting organizations are more likely to be located in countries with weaker employment protection laws. This finding might occur because, in these countries, the public debate over labour practices issues might be more heated than in countries with stronger employee protection laws. Thus, where such governmental laws are weaker, trade unions, employees, activists, shareholders, and society at large might exert greater pressure on organizations themselves, which in turn must be more proactive in voluntarily reporting on their labour practices and sustainability conduct and must address sustainability more strategically (Babiak and Trendafilova, 2011).

Concerning the hypotheses on the economic and financial system, the data did not show support for any of the hypotheses. The results even contradict hypothesis $H_{2 c}$, showing that SDG reporting organizations are more likely to be located in countries with lower levels of market coordination (i.e., primarily bank-based economies). This finding might reflect banks' emerging commitment to supporting organizations in improving their sustainability performance (Conley and Williams, 2011) and thus banks’ potential to stimulate sustainable development (Bouma et al., 2001; Campiglio, 2016).

In terms of socio-cultural systems, the results support $H_{3 e}$ and $H_{3 h}$, showing that organizations reporting on the Sustainable Development Goals are more likely to be located in countries with lower levels of power distance and higher levels of indulgence, thus confirming previous findings in the sustainability literature (e.g., Halkos and Skouloudis, 2017; Husted, 2005; Ringov and Zollo, 2007). However, the results contradict $H_{3 d}$ and $H_{3 g}$, showing that SDG reporting organizations are more likely to be located in more individualistic and more short-term-oriented countries. However, the result on the relationship between SDG reporting and individualism is coherent with what was found by Vachon (2010) and Husted (2005). In particular, Vachon (2010) found individualism to be related to green corporatism, environmental innovation, fair labour practices and corporate social involvement. Husted (2005) observed that countries with high levels of individualism have higher social and institutional capacity for environmental sustainability. In this regard, Husted (2005, p. 353), citing Katz et al. (2001), argued that “[e]nvironmental interest-group activity appears to be 
much more widespread and diverse in individualistic cultures than in collectivistic cultures. As a result, a country with a high individualistic tendency should have more environmental groups and thus have a greater social and institutional capacity to respond to environmental problems”. Similarly, a more individualistic country might also have more SDG interest groups and thus a greater social and institutional capacity to address the SDGs. Also concerning long-term orientation, the result does not seem to be an isolated case. Indeed, previous studies of sustainability reporting did not find support for the hypothesis of a positive relationship between sustainability reporting and long-term orientation (García-Sánchez et al., 2013). In particular, García-Sánchez et al. (2013) observed a negative impact of long-term orientation on integrated reporting, although the difference that they observed was not statistically significant. A possible explanation for these results is the short-termoriented countries' focus on achieving quick results (Hofstede et al., 2010). The SDGs were announced in 2015, and the authors analysed SDG reporting based on sustainability reports published in 2016. Thus, organizations located in countries characterized by a greater focus on achieving quick results might have been more prone to addressing the SDGs in their sustainability reports earlier.

Regarding country technology and innovation, the results do not show significant differences between SDG and non-SDG reporting organizations. A similar result was found by Halkos and Skouloudis (2018) regarding the link between national CSR penetration and national innovative capacity.

Concerning a country's educational and labour systems, the results of the analysis support $H_{5 b}$, showing that SDG reporting organizations are more likely to be based in countries with higher levels of company spending on tertiary education. $H_{5 a}$ and $H_{5 c}$, in contrast, are not supported. The results confirm the results of Jensen and Berg (2012), who found a positive relationship between a country's level of private expenditures on tertiary education and the adoption of integrated reporting among the companies located in this country. As hypothesized by Jensen and Berg (2012), organizations with higher levels of investment in tertiary education show stronger interest in discovering and adopting new research advancements, academic knowledge and management frameworks, including sustainability reporting frameworks (e.g., SDG reporting).

Concerning the sustainability of a country, the findings led us to accept hypothesis $H_{6 a}$. Indeed, SDG reporting organizations display higher average levels of national corporate responsibility than non-SDG reporting ones. This finding is in line with previous studies conducted by Jensen and Berg (2012), Kolk and Perego (2010), and Sotorrío and Sánchez (2010), showing that the level of corporate sustainability of a country can impact organizations’ sustainability performance.

Finally, the authors also accepted hypothesis $H_{6 e}$, which stated that SDG reporting organizations are more likely to be located in countries with higher levels of climate vulnerability. Indeed, according to the interpretation of the authors, organizations located in countries more vulnerable to climate 
change might experience greater political and social pressure to act more sustainably and are thus more likely to report on SDGs (Hassan and Ibrahim, 2012).

\section{Limitations and future research}

While this study provides a novel contribution to the emerging literature on the SDGs and SDG reporting, it also presents some limitations that must be considered when generalizing its findings.

First, this study is restricted to the investigation of the integration of SDGs into sustainability reports and does not include an assessment of actual organizational performance in terms of SDG advancement. Second, the study does not analyse internal organizational factors, such as organizational size, resources and capabilities, intangibility, and economic and sustainability performance. Third, as with all empirical studies, the limited sample size could have influenced the results of the study and affected their generalization. Fourth, the study relied only on organizations using GRI guidelines as a sustainability reporting framework, which might have introduced bias in the sample. Future studies might repeat the analysis by including organizations following alternative sustainability reporting guidelines. Fifth, some of the measures used to assess the institutional factors are not exempt from criticism, such as the Human Development Index (Wolff et al., 2011) and Hofstede's cultural dimensions (House et al., 2004).

Future studies might consider the effects on SDG reporting of internal organizational characteristics, such as size, resources and capabilities, intangibility, and economic and sustainability

performance. Such an analysis might be complemented by means of qualitative research methods to uncover motivations and drivers for voluntarily reporting on SDGs in different contexts.

Finally, future research might focus on individual motivations to engage with and report on the SDGs and even consider the influences of different personal and demographic variables on individual motivations.

Thus, SDG reporting, as well as being of crucial importance for the achievement of the sustainable development agenda, also offers significant opportunities for future research within the corporate sustainability academic domain.

\section{Conclusions}

SDG reporting can play a key role in the achievement of the SDGs worldwide. However, SDG reporting is still under-investigated in the corporate sustainability literature, and it is not yet clear 
what the factors are that might influence it. This study aimed to contribute to the corporate sustainability literature by analysing the relationship between various national institutional factors and SDG reporting. In particular, the authors first identified 27 major institutional factors potentially related to organization SDG reporting and then tested these factors empirically.

The results show that some of the identified institutional factors are significantly related to SDG reporting, with differences existing between SDG reporting and non-SDG reporting organizations. In particular, the authors found that organizations reporting on the Sustainable Development Goals are more likely to be located in countries with higher levels of climate change vulnerability, national CSR, and company spending on tertiary education. Moreover, according to the findings, SDG reporting organizations are more likely to be located in countries characterized by more indulgent, egalitarian, short-term-oriented and individualistic cultures and by weaker employment protection and market coordination laws.

This study contributes to the emerging research on SDGs by emphasizing the roles of sustainability and SDG reporting for the achievement of the Sustainable Development Agenda and investigating the relationship between SDG reporting and various country-level institutional factors.

From a managerial perspective, this study aims to support managers and decision makers in developing a better understanding of key institutional factors positively or negatively related to the integration of SDGs into corporate sustainability reports. This might be particularly relevant for multinational enterprises operating in countries with different institutional conditions. Indeed, in these situations, multinational enterprises might choose to develop country-specific SDG strategies and actions compensating for these institutional conditions, which are negatively related to SDG integration. For example, managers might consider the institutional conditions that characterize a particular business environment when designing training programmes for, and allocating resources to, SDG reporting. Such an analysis might also be useful for potential investors, shareholders and other stakeholders when evaluating the level of SDG integration of a particular organization exposed to certain institutional conditions. Furthermore, studies such as the one presented here can inform decision makers responsible for the development of country-specific policies, incentives and instruments aimed at supporting corporate SDG reporting and implementation. 


\section{References}

Adams, C.A., 2017. Conceptualising the contemporary corporate value creation process. Accounting, Auditing \& Accountability Journal 30, 906-931. doi:10.1108/AAAJ-04-2016-2529

Agarchand, N., Laishram, B., 2017. Sustainable infrastructure development challenges through PPP procurement process: Indian perspective. International Journal of Managing Projects in Business 10, 642-662. doi:10.1108/IJMPB-10-2016-0078

Aguinis, H., Glavas, A., 2012. What We Know and Don’t Know About Corporate Social Responsibility: A Review and Research Agenda. Journal of Management 38, 932-968. doi:10.1177/0149206311436079

Albassam, B. a, 2013. The Relationship Between Governance and Economic Growth During Times of Crisis. European Journal of Sustainable Development 2, 1-18. doi:10.14207/ejsd.2013.v2n2p1

Ali, A., Hwang, L.-S., 2000. Country-Specific Factors Related to Financial Reporting and the Value Relevance of Accounting Data. Journal of Accounting Research 38, 1-21. doi:10.2307/2672920

Ali, W., Frynas, J.G., Mahmood, Z., 2017. Determinants of Corporate Social Responsibility (CSR) Disclosure in Developed and Developing Countries: A Literature Review. Corporate Social Responsibility and Environmental Management 24, 273-294. doi:10.1002/csr.1410

Anasi, S., Ukangwa, A., Fagbe, C., 2018. University libraries-bridging digital gaps and accelerating the achievement of sustainable development goals through information and communication technologies. World Journal of Science, Technology and Sustainable Development 15, 13-25. doi:10.1108/WJSTSD-11-2016-0059

Babiak, K., Trendafilova, S., 2011. CSR and Environmental Responsibility: Motives and Pressures to Adopt Green Management Practices. Corporate Social Responsibility and Environmental Management 18, 11-24. doi:10.1002/csr.229

Bansal, P., 2005. Evolving sustainably: A longitudinal study of corporate sustainable development. Strategic Management Journal 26, 197-218. doi:10.1002/smj.441

Baughn, C.C., Bodie, N.L., McIntosh, J.C., 2007. Corporate social and environmental responsibility in Asian countries and other geographical regions. Corporate Social Responsibility \& Environmental Management 14, 189-205. doi:10.1002/csr.160

Bebbington, J., Russell, S., Thomson, I., 2017. Accounting and sustainable development: Reflections and propositions. Critical Perspectives on Accounting 48, 21-34. doi:10.1016/j.cpa.2017.06.002

Bebbington, J., Unerman, J., 2018. Achieving the United Nations Sustainable Development Goals: an enabling role for accounting research. Accounting, Auditing \& Accountability Journal 31, 224. doi:10.1108/AAAJ-05-2017-2929 
Biermann, F., Kanie, N., Kim, R.E., 2017. Global governance by goal-setting: the novel approach of the UN Sustainable Development Goals. Current Opinion in Environmental Sustainability 2627, 26-31. doi:10.1016/j.cosust.2017.01.010

Bocken, N.M.P., Short, S.W., Rana, P., Evans, S., 2014. A literature and practice review to develop sustainable business model archetypes. Journal of Cleaner Production 65, 42-56. doi:10.1016/j.jclepro.2013.11.039

Boons, F., Lüdeke-Freund, F., 2013. Business models for sustainable innovation: State-of-the-art and steps towards a research agenda. Journal of Cleaner Production 45, 9-19. doi:10.1016/j.jclepro.2012.07.007

Botta, E., Koźluk, T., 2014. Measuring Environmental Policy Stringency in OECD Countries: A Composite Index Approach. OECD Economics Department Working Papers. doi:10.1787/5jxrjnc45gvg-en

Bouma, J.J., Jeucken, M., Klinkers, L., 2001. Sustainable Banking. The Greening of Finance. Routledge, London (UK).

Bowen, K.J., Cradock-Henry, N.A., Koch, F., Patterson, J., Häyhä, T., Vogt, J., Barbi, F., 2017. Implementing the "Sustainable Development Goals": towards addressing three key governance challenges—collective action, trade-offs, and accountability. Current Opinion in Environmental Sustainability 26-27, 90-96. doi:10.1016/j.cosust.2017.05.002

Buhr, N., Freedman, M., 2001. Culture, Institutional Factors and Differences in Environmental Disclosure Between Canada and the United States. Critical Perspectives on Accounting 12, 293322. doi:10.1006/cpac.2000.0435

Calabrese, A., Costa, R., Rosati, F., 2016. Gender differences in customer expectations and perceptions of corporate social responsibility. Journal of Cleaner Production 116, 135-149. doi:10.1016/j.jclepro.2015.12.100

Campiglio, E., 2016. Beyond carbon pricing: The role of banking and monetary policy in financing the transition to a low-carbon economy. Ecological Economics 121, 220-230. doi:10.1016/j.ecolecon.2015.03.020

Chen, S., Bouvain, P., 2009. Is corporate responsibility converging? a comparison of corporate responsibility reporting in the USA, UK, Australia, and Germany. Journal of Business Ethics 87, 299-317. doi:10.1007/s10551-008-9794-0

Christofi, A., Christofi, P., Sisaye, S., 2012. Corporate sustainability: historical development and reporting practices. Management Research Review 35, 157-172. doi:10.1108/01409171211195170

Conley, J.M., Williams, C.A., 2011. Global banks as global sustainability regulators?: The equator principles. Law and Policy 33, 542-575. doi:10.1111/j.1467-9930.2011.00348.x 
Cox, P.L., Friedman, B. a, Tribunella, T., 2011. Relationships among Cultural Dimensions, National Gross Domestic Product, and Environmental Sustainability. Journal of Applied Business and Economics 12, 46-56.

Dellaportas, S., 2006. Making a difference with a discrete course on accounting ethics. Journal of Business Ethics 65, 391-404. doi:10.1007/s10551-006-0020-7

Delmas, M.A., Toffel, M.W., 2008. Organizational responses to environmental demands: Opening the black box. Strategic Management Journal 29, 1027-1055. doi:10.1002/smj.701

Donoher, W.J., 2017. The multinational and the legitimation of sustainable development. Transnational Corporations 24, 49-60. doi:10.18356/5dbad6d9-en

Duran, J.J., Bajo, N., 2014. Institutions as determinant factors of corporate responsibility strategies of multinational firms. Corporate Social Responsibility and Environmental Management 21, 301-317. doi:10.1002/csr.1308

Dyllick, T., Hockerts, K., 2002. Beyond the business case for corporate sustainability. Business Strategy and the Environment 11, 130-141. doi:10.1002/bse.323

Ebner, D., Baumgartner, R.J., 2006. The relationship between Sustainable Development and Corporate Social Responsibility, in: Corporate Responsibility Research Conference 2006. pp. $1-17$.

Eccles, R., Ioannou, I., Serafeim, G., 2012. Is sustainability now the key to corporate success? The Guardian.

Elias, R.Z., 2004. An Examination of Business Students' Perception of Corporate Social Responsibilities Before and After Bankruptcies. Journal of Business Ethics 52, 267-281. doi:10.1023/B:BUSI.0000037558.74693.d5

Elkington, J., 1998. Cannibals with Forks: the Triple Bottom Line of 21st Century Business. Capstone, Oxford (UK).

Fan, J.P.H., Wong, T.J., 2002. Corporate ownership structure and the informativeness of accounting earnings in East Asia. Journal of Accounting and Economics 33, 401-425. doi:10.1016/S01654101(02)00047-2

Fasan, M., Marcon, C., Mio, C., 2016. Institutional Determinants of IR Disclosure Quality, in: Mio, C. (Ed.), Integrated Reporting: A New Accounting Disclosure. pp. 181-203. doi:10.1057/978$1-137-55149-8$

Fernandez-Feijoo, B., Romera, S., Ruiz, S., 2012. Does board gender composition affect corporate social responsibility reporting? International Journal of Business and Social Science 3, 31-39.

Fortanier, F., Kolk, A., Pinkse, J., 2011. Harmonization in CSR Reporting: MNEs and Global CSR Standards. Management International Review 51, 665-696. doi:10.1007/s11575-011-0089-9

Furman, J.L., Porter, M.E., Stern, S., 2002. The determinants of national innovative capacity. 
Research Policy 31, 899-933. doi:10.1016/S0048-7333(01)00152-4

Gallego-Álvarez, I., Ortas, E., 2017. Corporate environmental sustainability reporting in the context of national cultures: A quantile regression approach. International Business Review 26, 337353. doi:10.1016/j.ibusrev.2016.09.003

García-Sánchez, I.M., Rodríguez-Ariza, L., Frías-Aceituno, J.V., 2013. The cultural system and integrated reporting. International Business Review 22, 828-838. doi:10.1016/j.ibusrev.2013.01.007

Garcia-Torres, S., Rey-Garcia, M., Albareda-Vivo, L., 2017. Effective disclosure in the fast-fashion industry: From sustainability reporting to action. Sustainability 9, 2256. doi:10.3390/su9122256

Geissdoerfer, M., Morioka, S.N., de Carvalho, M.M., Evans, S., 2018. Business models and supply chains for the circular economy. Journal of Cleaner Production 190, 712-721. doi:10.1016/j.jclepro.2018.04.159

Giannetti, B.F., Coscieme, L., Agostinho, F., Neto, G.C.O., Almeida, C., Huisingh, D., 2018. Synthesis of the discussions held at the International Workshop on Advances in Cleaner Production: Ten years working together for a sustainable future. Journal of Cleaner Production 183, 481-486. doi:10.1016/j.jclepro.2018.02.024

Gjølberg, M., 2009. Measuring the immeasurable? Constructing an index of CSR practices and CSR performance in 20 countries. Scandinavian Journal of Management 25, 10-22. doi:10.1016/j.scaman.2008.10.003

Global Reporting Initiative, 2018a. Business Reporting on the SDGs [WWW Document]. URL https://www.globalreporting.org/information/SDGs/Pages/Reporting-on-the-SDGs.aspx (accessed 1.17.18).

Global Reporting Initiative, 2018b. About Sustainability Reporting [WWW Document]. URL https://www.globalreporting.org/information/sustainability-reporting/Pages/default.aspx

Global Reporting Initiative, 2018c. GRI Sustainability Disclosure Database [WWW Document]. URL http://database.globalreporting.org/ (accessed 1.31.18).

Global Reporting Initiative, 2016a. What is Sustainability Reporting? [WWW Document]. URL http://database.globalreporting.org/SDG-12-6/about-sustainablility-reporting

Global Reporting Initiative, 2016b. GRI 101: Foundation 2016. Amsterdam (The Netherlands).

Goldberger, J.R., 2011. Conventionalization, civic engagement, and the sustainability of organic agriculture. Journal of Rural Studies 27, 288-296. doi:10.1016/j.jrurstud.2011.03.002

Grant, D., Trautner, M.N., Jones, A.W., 2004. Do Facilities with Distant Headquarters Pollute More? How Civic Engagement Conditions the Environmental Performance of Absentee Managed Plants. Social Forces 83, 189-214. doi:10.1353/sof.2004.0111

Gugler, P., 2015. Book review - World Investment Report 2014: Investing in the SDGs: An Action 
Plan, UNCTAD, United Nations, Geneva (2014). International Business Review 24, 541-542. doi:10.1016/j.ibusrev.2015.01.006

Hahn, R., Kühnen, M., 2013. Determinants of sustainability reporting: a review of results, trends, theory, and opportunities in an expanding field of research. Journal of Cleaner Production 59, 5-21. doi:10.1016/J.JCLEPRO.2013.07.005

Hák, T., Janoušková, S., Moldan, B., 2016. Sustainable Development Goals: A need for relevant indicators. Ecological Indicators 60, 565-573. doi:10.1016/j.ecolind.2015.08.003

Halkos, G., Skouloudis, A., 2018. Corporate social responsibility and innovative capacity: Intersection in a macro-level perspective. Journal of Cleaner Production. doi:10.1016/j.jclepro.2018.02.022

Halkos, G., Skouloudis, A., 2017. Revisiting the relationship between corporate social responsibility and national culture: A quantitative assessment. Management Decision 55, 595-613. doi:10.1108/MD-12-2016-0868

Halkos, G., Skouloudis, A., 2016. National CSR and institutional conditions: An exploratory study. Journal of Cleaner Production 139, 1150-1156. doi:10.1016/j.jclepro.2016.07.047

Hall, P.A., Gingerich, D.W., 2004. Varieties of Capitalism and Institutional Complementarities in the Political Economy: an Empirical Analysis, MPIfG Discussion Paper 04/5. Cologne.

Hassan, A., Ibrahim, E., 2012. Corporate Environmental Information Disclosure: Factors Influencing Companies’ Success in Attaining Environmental Awards. Corporate Social Responsibility and Environmental Management 19, 32-46. doi:10.1002/csr.278

Hofstede, G., 2001. Culture’s Consequences: Comparing Values, Behaviors, Institutions, and Organizations Across Nations. Sage Publications, London (UK).

Hofstede, G., Hofstede, G.J., Minkov, M., 2010. Cultures and Organizations: Software of the mind. McGraw-Hill.

Horbach, J., 2008. Determinants of environmental innovation-New evidence from German panel data sources. Research Policy 37, 163-173. doi:10.1016/j.respol.2007.08.006

House, R.J., Hanges, P.J., Javidan, M., Dorfman, P.W., Gupta, V., 2004. Culture, Leadership, and Organizations: The GLOBE Study of 62 Societies. Sage Publications, Thousand Oaks (CA).

Howard-Grenville, J., Davis, J., Dyllick, T., Joshi, A., Miller, C., Thau, S., Tsui, A.S., 2017. Special issue call for submissions: Sustainable development for a better world: Contributions of leadership, management, and organizations. Academy of Management Discoveries 3, 106-109. doi:10.5465/amd.2017.0023

Husted, B., 2005. Culture and ecology: A cross-national study of the determinants of environmental sustainability. Management International Review 45, 349-371. doi:10.2307/40836056

Jackson, G., Apostolakou, A., 2010. Corporate social responsibility in Western Europe: An 
institutional mirror or substitute? Journal of Business Ethics 94, 371-394. doi:10.1007/s10551009-0269-8

Jensen, J.C., Berg, N., 2012. Determinants of Traditional Sustainability Reporting Versus Integrated Reporting. An Institutionalist Approach. Business Strategy and the Environment 21, 299-316. doi:10.1002/bse.740

Jones, P., Comfort, D., Hillier, D., 2018. Common Ground: The sustainable development goals and the marketing and advertising industry. Journal of Public Affairs 18, e1619. doi:10.1002/pa.1619

Katz, J.P., Swanson, D.L., Nelson, L.K., 2001. Culture-Based Expectations of Corporate Citizenship: a Propositional Framework and Comparison of Four Cultures. International Journal of Organizational Analysis 9, 149-171. doi:10.1108/eb028931

Kelley, S.W., Donnelly, J.H., Skinner, S.J., 1990. Customer participation in service production and delivery. Journal of Retailing 63, 315-335.

Kolk, A., Kourula, A., Pisani, N., 2017. Multinational enterprises and the sustainable development goals: What do we know and how to proceed? Transnational Corporations 24, 09-32. doi:10.18356/6f5fab5e-en

Kolk, A., Perego, P., 2010. Determinants of the adoption of sustainability assurance statements: An international investigation. Business Strategy and the Environment 19, 182-198. doi:10.1002/bse.643

La Porta, R., Lopez-de-SIlanes, F., Shleifer, A., Vishny, R.W., 1998. Law and Finance. Journal of Political Economy 106, 11131-55. doi:10.1086/250042

Legendre, S., Coderre, F., 2013. Determinants of GRI G3 Application Levels: The Case of the Fortune Global 500. Corporate Social Responsibility and Environmental Management 20, 182192. doi:10.1002/csr.1285

Linnenluecke, M.K., Russell, S. V., Griffiths, A., 2009. Subcultures and sustainability practices: The impact on understanding corporate sustainability. Business Strategy and the Environment 18, 432-452. doi:10.1002/bse.609

Liu, X., Anbumozhi, V., 2009. Determinant factors of corporate environmental information disclosure: an empirical study of Chinese listed companies. Journal of Cleaner Production 17, 593-600. doi:10.1016/j.jclepro.2008.10.001

Lo, S.-F., 2010. Performance Evaluation for Sustainable Business: A Profitability and Marketability Framework. Corporate Social Responsibility and Environmental Management 17, 311-319. doi:10.1002/csr.214

Lozano, R., 2015. A holistic perspective on corporate sustainability drivers. Corporate Social Responsibility and Environmental Management 22, 32-44. doi:10.1002/csr.1325

Lozano, R., 2011. Addressing Stakeholders and Better Contributing to Sustainability through Game 
Theory. The Journal of Corporate Citizenship 43, 45-62. doi:10.9774/GLEAF.4700.2011.au.00004

Luthar, H.K., DiBattista, R.A., Gautschi, T., 1997. Perception of What the Ethical Climate is and What it Should be: The Role of Gender, Academic Status, and Ethical Education. Journal of Business Ethics 16, 205-217.

Mathur, K., Berwa, A., 2017. Sustainable competitiveness: redefining the future with technology and innovation. Journal of Sustainable Finance \& Investment 7, 290-306. doi:10.1080/20430795.2017.1300855

Matten, D., Moon, J., 2008. "Implicit" and "Explicit” CSR: A Conceptual Framework for a Comparative Understanding of Corporate Social Responsibility. Academy of Management Review. doi:10.5465/AMR.2008.31193458

McWilliams, A., Siegel, D., 2001. Corporate social responsibility: A theory of the firm perspective. Academy of management review 26, 117-127. doi:10.5465/AMR.2001.4011987

Montiel, I., 2008. Corporate social responsibility and corporate sustainability: Separate pasts, common futures. Organization and Environment. doi:10.1177/1086026608321329

Morioka, S.N., Bolis, I., Carvalho, M.M. de, 2018. From an ideal dream towards reality analysis: Proposing Sustainable Value Exchange Matrix (SVEM) from systematic literature review on sustainable business models and face validation. Journal of Cleaner Production 178, 76-88. doi:10.1016/j.jclepro.2017.12.078

Morioka, S.N., Bolis, I., Evans, S., Carvalho, M.M., 2017. Transforming sustainability challenges into competitive advantage: Multiple case studies kaleidoscope converging into sustainable business models. Journal of Cleaner Production 167, 723-738. doi:10.1016/j.jclepro.2017.08.118

Naidu, S., 2016. Does Human Development Influence Women’s Labour Force Participation Rate? Evidences from the Fiji Islands. Social Indicators Research 127, 1067-1084. doi:10.1007/s11205-015-1000-z

Nwabuzor, A., 2005. Corruption and Development: New Initiatives in Economic Openness and Strengthened Rule of Law. Journal of Business Ethics 59, 121-138. doi:10.1007/s10551-0053402-3

OECD, 2018a. OECD Indicators of Employment Protection [WWW Document]. URL http://www.oecd.org/employment/emp/oecdindicatorsofemploymentprotection.htm (accessed 3.27.18).

OECD, 2018b. Environmental Policy Stringency Index [WWW Document]. URL https://stats.oecd.org/ (accessed 3.27.18).

OECD, 2018c. Education and social outcomes: Civic engagement and governance [WWW 
Document]. URL http://stats.oecd.org/ (accessed 2.1.18).

OECD, 2018d. Survey of Adult Skills (PIAAC) [WWW Document]. URL http://www.oecd.org/skills/piaac/ (accessed 2.1.18).

OECD, 2018e. Spending on tertiary education (indicator) [WWW Document]. doi:10.1787/a3523185-en

OECD, 2018f. Trade Union [WWW Document]. URL http://stats.oecd.org/

OECD, 2011. “Towards Green Growth: Monitoring Progress.” OECD Green Growth Strategy 1-143. doi:10.1787/9789264111318-en

Orij, R., 2010. Corporate social disclosures in the context of national cultures and stakeholder theory. Accounting, Auditing \& Accountability Journal 23, 868-889. doi:10.1108/09513571011080162 Ortiz-de-Mandojana, N., Bansal, P., 2016. The long-term benefits of organizational resilience through sustainable business practices. Strategic Management Journal 37, 1615-1631. doi:10.1002/smj.2410

Pahl-Wostl, C., Tàbara, D., Bouwen, R., Craps, M., Dewulf, A., Mostert, E., Ridder, D., Taillieu, T., 2008. The importance of social learning and culture for sustainable water management. Ecological Economics 64, 484-495. doi:10.1016/j.ecolecon.2007.08.007

Park, H., Russell, C., Lee, J., 2007. National Culture and Environmental Sustainability: a CrossNational Analysis. Journal of Economics and Finance 31, 104-121.

Pedersen, E.R.G., Brusoni, M., Fontrodona, J., Matser, I., Sauquet, A., 2018. Governing SDGs: From Universal Agenda to Local Action [WWW Document]. Corporate Governance. URL http://www.emeraldgrouppublishing.com/products/journals/call_for_papers.htm?id=7451

Porter, M.E., van der Linde, C., 1995. Toward a New Conception of the EnvironmentCompetitiveness Relationship. Journal of Economic Perspectives 9, 97-118. doi:10.1257/jep.9.4.97

Portney, K., 2005. Civic engagement and sustainable cities in the United States. Public Administration Review 65, 579-591. doi:10.1111/j.1540-6210.2005.00485.x

Prado-Lorenzo, J., Rodríguez-Domínguez, L., Gallego-Álvarez, I., García-Sánchez, I.-M., 2009. Factors influencing the disclosure of greenhouse gas emissions in companies world-wide. Management Decision 47, 1133-1157. doi:10.1108/00251740910978340

Quazi, A.M., 2003. Identifying the determinants of corporate managers' perceived social obligations. Management Decision 41, 822-831. doi:10.1108/00251740310488999

Ringov, D., Zollo, M., 2007. Corporate responsibility from a socio-institutional perspective: The impact of national culture on corporate social performance. Corporate Governance 7, 476-485. doi:10.1108/14720700710820551

Rosati, F., Costa, R., Calabrese, A., Pedersen, E.R.G., 2018. Employee attitudes towards corporate 
social responsibility: a study on gender, age and educational level differences. Corporate Social Responsibility and Environmental Management. doi:10.1002/csr.1640

Rosati, F., Faria, L.G.D., 2018. Business contribution to the Sustainable Development Agenda: organizational factors related to early adoption of SDG reporting. Corporate Social Responsibility and Environmental Management. doi:10.1002/csr.1705

Roy, A., Goll, I., 2014. Predictors of various facets of sustainability of nations: The role of cultural and economic factors. International Business Review 23, 849-861. doi:10.1016/j.ibusrev.2014.01.003

Russell, S., Haigh, N., Griffiths, A., 2007. Understanding corporate sustainability, in: Benn, S., Dunphy, D.C. (Eds.), Corporate Governance and Sustainability: Challenges for Theory and Practice. Routledge, Abingdon (UK), pp. 36-56.

Sachs, J., Schmidt-Traub, G., Kroll, C., Durand-Delacre, D., Teksoz, K., 2017. SDG Index and Dashboards Report 2017. New York.

Salim, E., 2015. Pro-Growth, Pro-Job, Pro-Poor, Pro-Environment, in: Anbumozhi, V., Kawai, M., Lohani, B.N. (Eds.), Managing the Transition to a Low-Carbon Economy: Perspectives, Policies, and Practices from Asia. Asian Development Bank Institute, Tokyo, Japan, p. 391.

Schaltegger, S., Beckmann, M., Hansen, E.G., 2013. Transdisciplinarity in Corporate Sustainability: Mapping the Field. Business Strategy and the Environment 22, 219-229. doi:10.1002/bse.1772

Schönherr, N., Findler, F., Martinuzzi, A., 2017. Exploring the interface of CSR and the sustainable development goals. Transnational Corporations 24, 33-47. doi:10.18356/cfb5b8b6-en

Schramade, W., 2017. Investing in the UN Sustainable Development Goals: Opportunities for Companies and Investors. Journal of Applied Corporate Finance 29, 87-99. doi:10.1111/jacf.12236

Seitz, N., 2016. Linking CSR to national competitiveness and innovation, in: University Evolution, Entrepreneurial Activity and Regional Competitiveness. pp. 261-284. doi:10.1007/978-3-31917713-7_12

Shoaf, V., Jermakowicz, E.K., Epstein, B.J., 2018. Toward Sustainability and Integrated Reporting. Review of Business 38, 1-15.

Shutkin, W.A., 2003. The Land that Could Be: Environ-mentalism and Democracy in the TwentyFirst Century. MIT Press, Cambridge, MA.

Siebenhüner, B., Arnold, M., 2007. Organizational learning to manage sustainable development. Business Strategy and the Environment 16, 339-353. doi:10.1002/bse.579

Sims, R.L., Gong, B., Ruppel, C.P., 2012. A contingency theory of corruption: The effect of human development and national culture. Social Science Journal 49, 90-97. doi:10.1016/j.soscij.2011.07.005 
Skouloudis, A., Isaac, D., Evaggelinos, K., 2016. Revisiting the national corporate social responsibility index. International Journal of Sustainable Development and World Ecology 23, 61-70. doi:10.1080/13504509.2015.1099121

Sotorrío, L.L., Sánchez, J.L.F., 2010. Corporate social reporting for different audiences: The case of multinational corporations in Spain. Corporate Social Responsibility and Environmental Management 17, 272-283. doi:10.1002/csr.215

Stafford-Smith, M., Griggs, D., Gaffney, O., Ullah, F., Reyers, B., Kanie, N., Stigson, B., Shrivastava, P., Leach, M., O’Connell, D., 2017. Integration: the key to implementing the Sustainable Development Goals. Sustainability Science 12, 911-919.

Sullivan, K., Thomas, S., Rosano, M., 2018. Using industrial ecology and strategic management concepts to pursue the Sustainable Development Goals. Journal of Cleaner Production 174, 237246. doi:10.1016/j.jclepro.2017.10.201

Taylor, B.M., 2013. Sustainability and Performance Measurement: Corporate Real Estate Perspectives. Performance Improvement 52, 36-45. doi:10.1002/pfi

The Heritage Foundation, 2018. 2018 Index of Economic Freedom [WWW Document]. URL https://www.heritage.org/index/download (accessed 3.27.18).

The International Integrated Reporting Council, 2013. The International <IR $>$ Framework.

Thorlakson, T., de Zegher, J.F., Lambin, E.F., 2018. Companies’ contribution to sustainability through global supply chains. Proceedings of the National Academy of Sciences 115, 201716695. doi:10.1073/pnas.1716695115

Topple, C., Donovan, J.D., Masli, E.K., Borgert, T., 2017. Corporate sustainability assessments: MNE engagement with sustainable development and the SDGs. Transnational Corporations 24, 61-71. doi:10.18356/2ae5911c-en

United Nations Conference on Trade and Development, 2014. World Investment Report 2014: Investing in the SDGs: An Action Plan. New York and Geneva.

United Nations Development Programme, 2016. Human Development Report 2016. New York, NY.

United Nations General Assembly, 2015. Transforming our world: The 2030 agenda for sustainable development. New York.

United Nations Global Compact, 2018a. Global goals forpeople and planet [WWW Document]. URL https://www.unglobalcompact.org/sdgs/about (accessed 1.17.18).

United Nations Global Compact, 2018b. How Your Company Can Advance Each of the SDGs [WWW Document]. URL https://www.unglobalcompact.org/sdgs/17-global-goals (accessed 1.17.18).

United Nations Global Compact, 2018c. Reporting on the SDGs - Shape the future of corporate reporting on the SDGs [WWW Document]. URL https://www.unglobalcompact.org/take- 
action/action/sdg-reporting (accessed 1.17.18).

University of Notre Dame, 2018. ND-GAIN Country Index [WWW Document]. URL https://gain.nd.edu/our-work/country-index/rankings/ (accessed 2.1.18).

Vachon, S., 2010. International Operations and Sustainable Development: Should National Culture Matter? Sustainable Development 18, 350-361. doi:10.1002/sd

Verdolini, E., Bak, C., Ruet, J., Venkatachalam, A., 2017. Innovative green-technology SMEs as an opportunity to promote financial de-risking. Economics: The Open-Access, Open-Assessment E-Journal 12, 1-12. doi:10.5018/economics-ejournal.ja.2018-14

Vormedal, I.H., Ruud, A., 2009. Sustainability reporting in Norway - An assessment of performance in the context of legal demands and socio-political drivers. Business Strategy and the Environment 18, 207-222. doi:10.1002/bse.560

Williams, G., Zinkin, J., 2008. The effect of culture on consumers' willingness to punish irresponsible corporate behaviour: Applying Hofstede’s typology to the punishment aspect of corporate social responsibility. Business Ethics: A European Review 17, 210-226. doi:10.1111/j.14678608.2008.00532.x

WIPO, 2018. PCT - The International Patent System [WWW Document]. URL PCT - The International Patent System (accessed 3.31.18).

Witte, C., Dilyard, J., 2017. Guest editors' introduction to the special issue: The contribution of multinational enterprises to the Sustainable Development Goals. Transnational Corporations 24, 1-8. doi:10.18356/799ae8b0-en

Wolff, H., Chong, H., Auffhammer, M., 2011. Classification, Detection and Consequences of Data Error: Evidence from the Human Development Index. Economic Journal 121, 843-870. doi:10.1111/j.1468-0297.2010.02408.x

World Bank, 2018. GNI per capita, Atlas method (current US\$) [WWW Document]. URL https://data.worldbank.org/indicator/NY.GNP.PCAP.CD (accessed 3.27.18).

World Commission on Environment and Development, 1987. Report of the World Commission on Environment and Development: Our common future, Oxford paperbacks.

World Economic Forum, 2017a. The Global Competitiveness Report 2017-2018, World Economic Forum Report.

World Economic Forum, 2017b. Company spending on R\&D [WWW Document]. URL http://reports.weforum.org/global-competitiveness-index-2017-2018/competitivenessrankings/\#series=EOSQ118 (accessed 3.31.18).

World Economic Forum, 2017c. University-industry collaboration in R\&D [WWW Document]. URL http://reports.weforum.org/global-competitiveness-index-2017-2018/competitivenessrankings/\#series=EOSQ072 (accessed 3.31.18). 
World Economic Forum, 2017d. Capacity for innovation [WWW Document]. URL http://reports.weforum.org/global-competitiveness-index-2017-2018/competitivenessrankings/\#series=EOSQ119 (accessed 3.31.18).

World Economic Forum, 2017e. PCT Patents [WWW Document]. URL http://reports.weforum.org/global-competitiveness-index-2017-2018/competitivenessrankings/\#series=PCTPATENTAPPLPC (accessed 3.31.18).

Yale University, 2018. 2018 EPI Results [WWW Document]. URL https://epi.envirocenter.yale.edu/epi-topline (accessed 2.1.18).

Zhao, R., Millet-Reyes, B., 2007. Ownership Structure and Accounting Information Content: Evidence from France. Journal of International Financial Management \& Accounting 18, 223246. doi:10.1111/j.1467-646X.2007.01013.x 


\section{Tables}

\begin{tabular}{|c|c|c|c|c|}
\hline $\begin{array}{c}\text { Research } \\
\text { hypothesis }\end{array}$ & $\begin{array}{l}\text { Institutional } \\
\text { system }\end{array}$ & $\begin{array}{l}\text { Institutional } \\
\text { factor }\end{array}$ & Description & Data source \\
\hline$H_{1 a}$ & \multirow{3}{*}{$\begin{array}{l}\text { Politics and } \\
\quad \text { law }\end{array}$} & PL-COCI & Common/civil law & La Porta et al. (1998) \\
\hline$H_{1 b}$ & & PL-EMPR & Employment protection & OECD (2018a) \\
\hline$H_{1 c}$ & & PL-EPSI & Environmental policy stringency & OECD (2018b) \\
\hline$H_{2 a}$ & \multirow{4}{*}{$\begin{array}{l}\text { Economics } \\
\text { and finance }\end{array}$} & EF-GNI & Economic development & World Bank (2018) \\
\hline$H_{2 b}$ & & EF-EFI & Economic freedom & The Heritage Foundation (2018) \\
\hline$H_{2 c}$ & & EF-COOR & Market coordination & Hall and Gingerich (2004) \\
\hline$H_{2 d}$ & & EF-OWNE & Ownership concentration & La Porta et al. (1998) \\
\hline$H_{3 a}$ & \multirow{8}{*}{$\begin{array}{l}\text { Society and } \\
\text { culture }\end{array}$} & SC-IHDI & Human development & United Nations Development Programme (2016) \\
\hline$H_{3 b}$ & & SC-CEG & Civic engagement & OECD (2018c) \\
\hline$H_{3 c}$ & & SC-MAS & Masculinity & Hofstede (2001) \\
\hline$H_{3 d}$ & & SC-IND & Individualism & Hofstede (2001) \\
\hline$H_{3 e}$ & & SC-POW & Power distance & Hofstede (2001) \\
\hline$H_{3 f}$ & & SC-UNC & Uncertainty avoidance & Hofstede (2001) \\
\hline$H_{3 g}$ & & SC-LTO & Long-term orientation & Hofstede et al. (2010) \\
\hline$H_{3 h}$ & & SC-IVR & Indulgence versus restraint & Hofstede et al. (2010) \\
\hline$H_{4 a}$ & \multirow{4}{*}{$\begin{array}{l}\text { Technology } \\
\text { and } \\
\text { innovation }\end{array}$} & TI-RDEX & Company spending on R\&D & World Economic Forum (2017b) \\
\hline$H_{4 b}$ & & TI-UIRD & University-industry collaboration in R\&D & World Economic Forum (2017c) \\
\hline$H_{4 c}$ & & TI-INCA & Capacity for innovation & World Economic Forum (2017d) \\
\hline$H_{4 d}$ & & TI-PAT & Technological knowledge & World Economic Forum (2017e) \\
\hline$H_{5 a}$ & \multirow{3}{*}{$\begin{array}{l}\text { Education and } \\
\text { labour }\end{array}$} & EL-EDI & Education & United Nations Development Programme (2016) \\
\hline$H_{5 b}$ & & EL-EDS & Company spending on tertiary education & OECD (2018e) \\
\hline$H_{5 c}$ & & EL-TUD & Trade union density & OECD (2018f) \\
\hline$H_{6 a}$ & \multirow{5}{*}{ Sustainability } & SU-NCSRI & National corporate responsibility & Skouloudis et al. (2016) \\
\hline$H_{6 b}$ & & SU-EPI & Environmental performance & Yale University (2018) \\
\hline$H_{6 c}$ & & SU-SDGI & Sustainable development & Sachs et al. (2017) \\
\hline$H_{6 d}$ & & SU-READY & Climate adaptation readiness & University of Notre Dame (2018) \\
\hline$H_{6 e}$ & & SU-VULN & Climate vulnerability & University of Notre Dame (2018) \\
\hline
\end{tabular}

Table 1: Research hypotheses, by institutional systems and institutional factors. 


\begin{tabular}{|c|c|c|c|c|c|c|c|c|c|c|c|}
\hline \multirow{2}{*}{ Research hypothesis } & \multirow{2}{*}{ Institutional system } & \multirow{2}{*}{ Variable } & \multirow{2}{*}{$\begin{array}{c}\text { Common/Civil } \\
\text { Law }\end{array}$} & \multicolumn{3}{|c|}{ Organizations } & \multicolumn{2}{|c|}{ Std. residual } & \multicolumn{3}{|c|}{ Pearson chi } \\
\hline & & & & SDG & NSDG & Total & SDG & NSDG & Pearson chi-square & Asymp. sign. (2-sided) & Phi \\
\hline \multirow{2}{*}{$H_{1 a}$} & \multirow{2}{*}{ Politics and law } & \multirow{2}{*}{ PL-COCI } & Common Law & 79 & 310 & 389 & 2.8 & -1.2 & 12.040 & 0.001 & 0.083 \\
\hline & & & Civil Law & 179 & 1,175 & 1,354 & -1.5 & 0.6 & & & \\
\hline
\end{tabular}

Table 2: Differences in the categorical variable PL-COCI between organizations that report on the SDGs and organizations that do not report on the SDGs.

$S D G=$ organizations that report on the SDGs, NSDG = organizations that do not report on the SDGs.

$S D G N=204, N S D G N=105 . D f=1$.

Acceptance/rejection threshold: phi $=0.10$. 


\begin{tabular}{|c|c|c|c|c|c|c|c|c|c|}
\hline \multirow{2}{*}{$\begin{array}{l}\text { Research } \\
\text { hypothesis }\end{array}$} & \multirow{2}{*}{$\begin{array}{l}\text { Institutional } \\
\text { system }\end{array}$} & \multirow{2}{*}{$\begin{array}{l}\text { Independent } \\
\text { variable }\end{array}$} & \multicolumn{2}{|c|}{ Mean } & \multirow{2}{*}{$\begin{array}{c}\text { Mann- } \\
\text { Whitney U }\end{array}$} & \multirow{2}{*}{ Wilcoxon W } & \multirow{2}{*}{$\mathbf{Z}$} & \multirow{2}{*}{$\begin{array}{l}\text { Asymp. sign. } \\
\text { (2-tailed) }\end{array}$} & \multirow{2}{*}{$\begin{array}{l}\text { Acceptance } \\
\text { rejection }\end{array}$} \\
\hline & & & SDG & NSDG & & & & & \\
\hline$H_{1 b}$ & \multirow{2}{*}{$\begin{array}{l}\text { Politics and } \\
\text { law }\end{array}$} & PL-EMPR & 2.135 & 2.265 & 209592.000 & 251497.000 & -3.819 & 0.000 & Rejected** \\
\hline$H_{1 c}$ & & PL-EPSI & 2.823 & 2.719 & 142046.500 & 1037837.500 & -1.869 & 0.062 & \\
\hline $\mathrm{H}_{2 a}$ & \multirow{4}{*}{$\begin{array}{l}\text { Economics } \\
\text { and finance }\end{array}$} & EF-GNI & 33232.438 & 32945.342 & 293300.000 & 345950.000 & -0.056 & 0.956 & \\
\hline$H_{2 b}$ & & EF-EFI & 70.247 & 70.440 & 334436.000 & 390716.000 & -1.112 & 0.266 & \\
\hline$H_{2 c}$ & & EF-COOR & 0.464 & 0.530 & 83636.000 & 101591.000 & -2.287 & 0.022 & Rejected* \\
\hline$H_{2 d}$ & & EF-OWNE & 0.397 & 0.396 & 270379.500 & 1956745.500 & -1.322 & 0.186 & \\
\hline$H_{3 a}$ & \multirow{8}{*}{$\begin{array}{l}\text { Society and } \\
\text { culture }\end{array}$} & SC-IHDI & 0.729 & 0.717 & 238517.500 & 286412.500 & -1.737 & 0.082 & \\
\hline$H_{3 b}$ & & SC-CEG & 50.660 & 50.871 & 106898.500 & 677744.500 & -0.315 & 0.752 & \\
\hline$H_{3 c}$ & & SC-MAS & 51.359 & 49.237 & 289614.500 & 2286615.500 & -1.755 & 0.079 & \\
\hline$H_{3 d}$ & & SC-IND & 56.738 & 50.111 & 265465.000 & 2262466.000 & -3.974 & 0.000 & Rejected** \\
\hline$H_{3 e}$ & & SC-POW & 49.974 & 52.762 & 285471.000 & 333366.000 & -2.135 & 0.033 & Accepted* \\
\hline$H_{3 f}$ & & SC-UNC & 61.563 & 63.090 & 290786.000 & 338681.000 & -1.646 & 0.100 & \\
\hline$H_{3 g}$ & & SC-LTO & 45.542 & 54.006 & 253655.000 & 302483.000 & -5.375 & 0.000 & Rejected** \\
\hline$H_{3 h}$ & & SC-IVR & 57.314 & 53.702 & 268270.500 & 2203798.500 & -3.330 & 0.001 & Accepted** \\
\hline$H_{4 a}$ & \multirow{4}{*}{$\begin{array}{l}\text { Technology } \\
\text { and } \\
\text { innovation }\end{array}$} & TI-RDEX & 4.548 & 4.579 & 341286.500 & 396897.500 & -0.288 & 0.774 & \\
\hline$H_{4 b}$ & & TI-UIRD & 4.523 & 4.539 & 342004.500 & 2485489.500 & -0.226 & 0.821 & \\
\hline$H_{4 c}$ & & TI-INCA & 5.010 & 4.982 & 335586.500 & 2479071.500 & -0.776 & 0.438 & \\
\hline$H_{4 d}$ & & TI-PAT & 107.729 & 109.372 & 281526.500 & 333852.500 & -0.859 & 0.390 & \\
\hline$H_{5 a}$ & \multirow{3}{*}{$\begin{array}{l}\text { Education and } \\
\text { labour }\end{array}$} & EL-EDI & 0.793 & 0.798 & 293521.500 & 1974382.500 & -0.507 & 0.612 & \\
\hline$H_{5 b}$ & & EL-EDS & 11.287 & 10.111 & 103319.000 & 725489.000 & -1.983 & 0.047 & Accepted* \\
\hline$H_{5 c}$ & & EL-TUD & 31.755 & 32.167 & 63150.500 & 464110.500 & -0.254 & 0.800 & \\
\hline$H_{6 a}$ & \multirow{5}{*}{ Sustainability } & SU-NCSRI & -7.813 & -9.451 & 315440.500 & 2456855.500 & -2.308 & 0.021 & Accepted* \\
\hline$H_{6 b}$ & & SU-EPI & 68.366 & 68.783 & 337906.500 & 393851.500 & -0.325 & 0.745 & \\
\hline$H_{6 c}$ & & SU-SDGI & 73.008 & 74.130 & 274256.500 & 327231.500 & -1.809 & 0.070 & \\
\hline$H_{6 d}$ & & SU-READY & 0.577 & 0.583 & 268497.000 & 318583.000 & -0.405 & 0.685 & \\
\hline$H_{6 e}$ & & SU-VULN & 0.357 & 0.347 & 250897.000 & 1734400.000 & -2.205 & 0.027 & Accepted* \\
\hline
\end{tabular}

Table 3: Results, by institutional factor.

$S D G=$ organizations that report on the SDGs, NSDG = organizations that do not report on the SDGs.

Acceptance/rejection threshold: asymp. sign. (2-tailed) $=0.05$.

Statistical significance: ${ }^{*}$-value $<0.05,{ }^{* *}$-value $<0.01$. 


\section{Appendix}

\begin{tabular}{|c|c|c|c|c|c|c|c|c|c|c|c|c|c|c|c|c|c|c|c|c|c|c|c|c|c|c|c|c|c|}
\hline & \multirow{2}{*}{$\mathrm{N}(\mathrm{Tot})$} & \multirow{2}{*}{$\mathrm{N}(\mathrm{SDG})$} & \multicolumn{3}{|c|}{$\begin{array}{l}\text { Politics and Law (PL) } \\
\end{array}$} & Eco & omics an & Finance ( & & & & & ociety and & Culture & & & & Tech & ology and & Innovation & & Educati & in and Lal & ur $(\mathrm{EL})$ & & & istainabilit & $\mathrm{y}(\mathrm{SU})$ & \\
\hline & & & COCI & EMPR & EPSI & GNI & EFI & $\mathrm{COOR}$ & OWNE & IHDI & CEG & MAS & IND & POW & UNC & LTO & IVR & RDEX & UIRD & INCA & PAT & EDI & EDS & TUD & NCSRI & EPI & SDGI & READY & VULN \\
\hline $\begin{array}{l}\text { Andorra } \\
\end{array}$ & 1 & - & & & - & & & - & & & - & - & - & - & - & - & 65.0 & - & - & - & - & 0.7 & - & - & & & & & \\
\hline Angola & 1 & 1 & Civil & & - & 3450.0 & 48.6 & - & - & 0.3 & - & - & & - & - & - & - & - & & - & - & 0.5 & - & - & - & 37.4 & 50.2 & 0.2 & 0.5 \\
\hline Argentina & 64 & 4 & Civil & 2.6 & & 11970.0 & 52.3 & - & 0.5 & 0.7 & - & 56.0 & 46.0 & 49.0 & 86.0 & 20.0 & 62.0 & 3.1 & 3.3 & 4.1 & 1.2 & 0.8 & 0.0 & - & -28.4 & 59.3 & 72.5 & 0.4 & 0.4 \\
\hline Australia & 56 & 14 & Common & 1.9 & 3.7 & 54420.0 & 80.9 & 0.4 & 0.3 & 0.9 & 53.0 & 61.0 & 90.0 & 36.0 & 51.0 & 21.0 & 71.0 & 4.4 & 4.3 & 5.1 & 77.7 & 0.9 & 13.6 & - & 6.2 & 74.1 & 75.9 & 0.7 & 0.3 \\
\hline Austria & 34 & 7 & Civil & 2.4 & 2.9 & 45790.0 & 71.8 & 1.0 & 0.6 & 0.8 & 44.0 & 79.0 & 55.0 & 11.0 & 70.0 & 60.0 & 63.0 & 4.9 & 4.8 & 5.6 & 174.7 & 0.8 & 2.6 & 28.0 & -12.2 & 79.0 & 81.4 & 0.7 & 0.3 \\
\hline Bahrain & 1 & 1 & - & & & & 67.7 & . & & 0.0 & & & & & & & & 3.4 & 3.7 & 4.1 & 2.9 & 0.7 & & 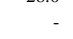 & -25.4 & 55.2 & 64.6 & 0.4 & 0.5 \\
\hline Bangladesh & 3 & 1 & - & - & - & 1330.0 & 55.1 & - & - & 0.4 & & 55.0 & 20.0 & 80.0 & 60.0 & 47.0 & 20.0 & 2.8 & 2.5 & 3.8 & 0.0 & 0.5 & - & - & -34.9 & 29.6 & 56.2 & 0.3 & 0.5 \\
\hline Belarus & 1 & - & Civil & & & 5590.0 & 58.1 & - & & 0.7 & & & & 0.0 & & 81.0 & 15.0 & & & & & 0.8 & 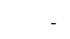 & - & -30.2 & 65.0 & 77.1 & & 0.0 \\
\hline Belgium & 32 & 6 & Civil & 3.0 & 2.5 & 41820.0 & 67.5 & 0.7 & 0.5 & 0.8 & 46.0 & 54.0 & 75.0 & 65.0 & 94.0 & 82.0 & 57.0 & 5.2 & 5.3 & 5.5 & 110.4 & 0.8 & 5.9 & 55.0 & -1.2 & 77.4 & 80.0 & 0.6 & 0.4 \\
\hline Bolivia & 2 & - & Civil & 1.9 & - & 3070.0 & 44.1 & - & - & 0.5 & - & & & - & - & & - & & & & & 0.7 & - & - & -28.4 & 56.0 & 64.7 & 0.3 & 0.5 \\
\hline Botswana & 1 & . & - & 1.5 & 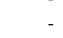 & 6750.0 & 69.9 & . & . & 0.4 & - & - & - & - & - & - & - & 3.0 & 3.3 & 3.7 & 0.0 & 0.7 & - & - & -20.4 & 51.7 & 58.3 & 0.4 & 0.5 \\
\hline Brazil & 39 & 4 & Civil & 1.7 & 0.4 & 8840.0 & 51.4 & - & 0.6 & 0.6 & - & 49.0 & 38.0 & 69.0 & 76.0 & 44.0 & 59.0 & 3.4 & 3.4 & 4.1 & 3.4 & 0.7 & - & - & -11.7 & 60.7 & 69.5 & 0.4 & 0.4 \\
\hline Bulgaria & 1 & & Civil & & & 7580.0 & 68.3 & 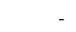 & & 0.7 & & 40.0 & 30.0 & 70.0 & 85.0 & 69.0 & 16.0 & 3.6 & 3.4 & 4.2 & 7.4 & 0.8 & & & -19.7 & 67.9 & 72.5 & 0.5 & 0.3 \\
\hline Canada & 55 & 2 & Common & 1.5 & 3.4 & 43660.0 & 77.7 & 0.1 & 0.4 & 0.8 & 49.0 & 52.0 & 80.0 & 39.0 & 48.0 & 36.0 & 68.0 & 4.3 & 4.6 & 5.1 & 88.8 & 0.9 & 25.3 & 29.8 & -0.8 & 72.2 & 78.0 & 0.7 & 0.3 \\
\hline Cape Verde & 1 & . & Civil & & & 2970.0 & 60.0 & & & 0.5 & & & & & & & & 3.0 & 3.2 & 3.7 & 0.0 & 0.5 & & & & 56.9 & & 0.4 & \\
\hline Chile & 25 & - & Civil & 1.8 & & 13540.0 & 75.2 & - & 0.5 & 0.7 & 93.0 & 28.0 & 23.0 & 63.0 & 86.0 & 31.0 & & 3.0 & 3.5 & 4.0 & 8.8 & 0.8 & 10.6 & 14.2 & -15.1 & 57.5 & 71.6 & 0.6 & 0.3 \\
\hline China & 70 & - & - & 3.0 & 2.0 & 8250.0 & 57.8 & - & & & & 66.0 & 20.0 & 80.0 & 30.0 & 87.0 & 24.0 & 4.6 & 4.4 & 4.5 & 17.7 & 0.6 & & - & -26.7 & 50.7 & 67.1 & 0.5 & 0.4 \\
\hline Colombia & 68 & 13 & Civil & 2.3 & - & 6310.0 & 68.9 & - & 0.6 & 0.5 & - & 64.0 & 13.0 & 67.0 & 80.0 & 13.0 & 83.0 & 3.1 & 3.6 & 3.8 & 2.1 & 0.6 & 0.0 & - & -12.0 & 65.2 & 64.8 & 0.4 & 0.4 \\
\hline Costa Rica & 3 & 2 & Civil & 1.2 & - & 10840.0 & 65.6 & - & - & 0.6 & - & 21.0 & 15.0 & 35.0 & 86.0 & - & - & 3.5 & 3.6 & 4.5 & 2.8 & 0.7 & - & - & -27.8 & 67.9 & 69.8 & 0.5 & 0.4 \\
\hline Côte d'Ivoire & 3 & 1 & & & - & 1520.0 & 62.0 & - & - & 0.3 & & & & & & & & & & & & 0.4 & - & - & & 45.3 & 53.3 & 0.3 & 0.5 \\
\hline Croatia & 3 & - & Civil & 2.3 & & 12140.0 & 61.0 & - & - & 0.8 & & 40.0 & 33.0 & 73.0 & 80.0 & 58.0 & 33.0 & 3.0 & 2.7 & 3.4 & 9.5 & 0.8 & - & & -23.1 & 65.5 & 76.9 & - & - \\
\hline Czech Republic & 3 & - & Civil & 2.7 & 2.4 & 17540.0 & 74.2 & & & 0.8 & 29.0 & 57.0 & 58.0 & 57.0 & 74.0 & 70.0 & 29.0 & 4.2 & 3.9 & 4.9 & 24.4 & 0.9 & & 15.1 & -26.3 & 67.7 & 81.9 & & \\
\hline Denmark & 10 & 5 & Civil & 2.3 & 3.8 & 56990.0 & 76.6 & 0.7 & 0.5 & 0.9 & 61.0 & 16.0 & 74.0 & 18.0 & 23.0 & 35.0 & 70.0 & 5.0 & 4.8 & 5.3 & 214.1 & 0.9 & 5.3 & 67.2 & 12.6 & 81.6 & 84.2 & 0.8 & 0.3 \\
\hline Ecuador & 13 & 4 & Civil & 1.8 & & 5800.0 & 48.5 & - & & 0.6 & & 63.0 & 8.0 & 78.0 & 67.0 & & & 2.8 & 3.0 & 3.7 & 0.3 & 0.7 & & - & -28.1 & 57.4 & 69.0 & 0.3 & 0.4 \\
\hline Egypt & 1 & - & - & - & - & 3410.0 & 53.4 & - & 0.6 & 0.5 & & . & 0.0 & - & - & 7.0 & 4.0 & 2.9 & 2.8 & 3.4 & 0.9 & 0.6 & - & - & -31.5 & 61.2 & 64.9 & 0.3 & 0.4 \\
\hline Estonia & 2 & - & Civil & 2.1 & & 17750.0 & 78.8 & - & - & 0.8 & 44.0 & 30.0 & 60.0 & 40.0 & 60.0 & 82.0 & 16.0 & 3.8 & 3.9 & 4.9 & 27.2 & 0.9 & - & 6.5 & -25.1 & 64.3 & 78.6 & - & - \\
\hline Finland & 76 & 8 & Civil & 2.2 & 3.4 & 45050.0 & 74.1 & 0.7 & 0.4 & 0.8 & 61.0 & 26.0 & 63.0 & 33.0 & 59.0 & 38.0 & 57.0 & 5.3 & 5.6 & 5.6 & 265.1 & 0.8 & 3.5 & 67.3 & 19.0 & 78.6 & 84.0 & 0.8 & 0.3 \\
\hline France & 27 & 3 & Civil & 2.8 & 3.6 & 38720.0 & 63.9 & 0.7 & 0.3 & 0.8 & & 43.0 & 71.0 & 68.0 & 86.0 & 63.0 & 48.0 & 5.2 & 4.2 & 5.5 & 126.6 & 0.8 & 9.6 & 8.1 & 2.6 & 84.0 & 80.3 & 0.6 & 0.3 \\
\hline Germany & 113 & 13 & Civil & 2.8 & 2.9 & 43850.0 & 74.2 & 1.0 & 0.5 & 0.9 & 35.0 & 66.0 & 67.0 & 35.0 & 65.0 & 83.0 & 40.0 & 5.6 & 5.4 & 5.8 & 218.9 & 0.9 & & 18.3 & -3.9 & 78.4 & 81.7 & 0.7 & 0.3 \\
\hline Greece & 36 & 6 & Civil & 2.4 & 2.1 & 19090.0 & 57.3 & - & 0.7 & 0.8 & 87.0 & 57.0 & 35.0 & 60.0 & 112.0 & 45.0 & 50.0 & 3.1 & 2.5 & 3.9 & 11.1 & 0.8 & - & 21.8 & -15.4 & 73.6 & 72.9 & 0.5 & 0.3 \\
\hline Honduras & 2 & - & Civil & 2.4 & & 2150.0 & 60.6 & - & & 0.4 & & & & & & & & 2.9 & 3.0 & 3.9 & 0.0 & 0.5 & - & - & -30.4 & 51.5 & 61.7 & 0.3 & 0.5 \\
\hline Hong Kong & 30 & 1 & & & & 43240.0 & 90.2 & - & 0.5 & & - & 57.0 & 25.0 & 68.0 & 29.0 & 61.0 & 17.0 & 4.4 & 4.9 & 4.9 & & 0.8 & - & & -5.4 & & & & - \\
\hline Hungary & 7 & - & Civil & 2.1 & 2.6 & 12570.0 & 66.7 & - & - & 0.8 & - & 88.0 & 80.0 & 46.0 & 82.0 & 58.0 & 31.0 & 3.1 & 3.4 & 3.8 & 24.7 & 0.8 & - & 11.8 & -19.5 & 65.0 & 78.0 & 0.5 & 0.4 \\
\hline Iceland & 2 & - & Civil & 2.5 & & 56990.0 & 77.0 & - & & 0.9 & - & & & & & 28.0 & 67.0 & 4.5 & 4.7 & 5.0 & 108.2 & 0.9 & 0.6 & - & -26.4 & 78.6 & 79.3 & 0.7 & 0.3 \\
\hline India & 45 & 6 & - & 2.6 & 1.3 & 1670.0 & 54.5 & - & 0.4 & 0.5 & - & 56.0 & 48.0 & 77.0 & 40.0 & 51.0 & 26.0 & 4.5 & 4.4 & 4.5 & 1.7 & 0.5 & - & - & -20.6 & 30.6 & 58.1 & 0.3 & 0.5 \\
\hline Indonesia & 13 & 3 & - & 2.9 & 1.2 & 3400.0 & 64.2 & & 0.6 & 0.6 & - & 46.0 & 14.0 & 78.0 & 48.0 & 62.0 & 38.0 & 4.4 & 4.3 & 4.8 & 0.1 & 0.6 & - & - & -25.0 & 46.9 & 62.9 & 0.4 & 0.4 \\
\hline Ireland & 2 & 1 & Common & 2.1 & 2.0 & 51760.0 & 80.4 & 0.3 & 0.4 & 0.9 & 42.0 & 68.0 & 70.0 & 28.0 & 35.0 & 24.0 & 65.0 & 4.8 & 5.0 & 5.2 & 89.9 & 0.9 & 4.8 & 34.2 & -5.7 & 78.8 & 77.9 & 0.7 & 0.3 \\
\hline Israel & 16 & 3 & & 2.2 & & 36240.0 & 72.2 & & 0.5 & 0.8 & 48.0 & 47.0 & 54.0 & 13.0 & 81.0 & 38.0 & & 5.8 & 5.7 & 5.9 & 247.1 & 0.9 & 20.7 & 22.8 & -13.6 & 75.0 & 70.1 & 0.6 & 0.3 \\
\hline Italy & 70 & 12 & Civil & 2.9 & 2.8 & 31730.0 & 62.5 & 0.9 & 0.6 & 0.8 & 31.0 & 70.0 & 76.0 & 50.0 & 75.0 & 61.0 & 30.0 & 3.9 & 3.8 & 4.9 & 57.5 & 0.8 & 7.8 & 36.3 & -1.6 & 77.0 & 75.5 & 0.5 & 0.3 \\
\hline Japan & 26 & 5 & - & 2.1 & 3.5 & 37930.0 & 72.3 & 0.7 & 0.2 & 0.8 & 38.0 & 95.0 & 46.0 & 54.0 & 92.0 & 88.0 & 42.0 & 5.6 & 4.7 & 5.1 & 332.4 & 0.8 & 15.1 & 17.9 & -0.3 & 74.7 & 80.2 & 0.7 & 0.4 \\
\hline Jersey & 1 & & - & & & & & - & & & & & & & & & & & & & & & - & - & & & & & \\
\hline Jordan & 4 & 2 & - & - & - & 3920.0 & 64.9 & - & - & 0.6 & - & - & - & - & - & 16.0 & 43.0 & 3.4 & 3.5 & 4.2 & 0.5 & 0.7 & - & - & -25.2 & 62.2 & 66.0 & 0.4 & 0.4 \\
\hline Kazakhstan & 2 & & Civil & 2.3 & - & 8810.0 & 69.1 & - & - & 0.7 & - & - & - & - & - & - & - & 3.0 & 3.3 & 3.9 & 1.3 & 0.8 & - & - & -27.5 & 54.6 & 71.1 & - & - \\
\hline Kenya & 1 & 1 & - & - & . & 1380.0 & 54.7 & & . & 0.4 & - & - & $=$ & . & & . & - & $\begin{array}{l}3.0 \\
3.9\end{array}$ & 4.3 & 4.7 & 0.2 & 0.5 & - & - & -30.8 & 47.3 & 54.9 & 0.3 & 0.6 \\
\hline Kuwait & 4 & 1 & - & & & 34890.0 & 62.2 & - & - & & 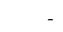 & - & - & - & - & & & 2.8 & 2.9 & 3.7 & 0.3 & 0.6 & - & - & -30.7 & 62.3 & 62.4 & 0.4 & 0.4 \\
\hline Latvia & 1 & - & Civil & 2.9 & - & 14570.0 & 73.6 & - & - & 0.7 & - & - & - & - & - & 69.0 & 13.0 & 3.2 & 3.1 & 4.2 & 11.8 & 0.8 & - & 13.1 & -24.8 & 66.1 & 75.2 & & \\
\hline Lebanon & 1 & - & & & - & 7980.0 & 53.2 & - & - & 0.6 & - & - & - & - & - & & & 3.2 & 3.6 & 4.5 & 2.4 & 0.7 & - & - & & 61.1 & 64.9 & 0.3 & 0.4 \\
\hline Liechtenstein & 1 & - & Civil & & & & & - & - & & & - & - & - & - & & & & & & & 0.8 & - & & & & & 0.6 & - \\
\hline Lithuania & 1 & - & Civil & 2.4 & - & 14750.0 & 75.3 & - & - & 0.8 & 79.0 & & & & & 82.0 & 16.0 & 3.9 & 4.1 & 4.8 & 15.9 & 0.9 & & 9.0 & -20.9 & 69.3 & 73.6 & & - \\
\hline Luxembourg & 6 & 1 & Civil & 2.7 & - & 71470.0 & 76.4 & - & - & 0.8 & - & 50.0 & 60.0 & 40.0 & 70.0 & 64.0 & 56.0 & 5.2 & 4.8 & 5.6 & 129.3 & 0.8 & 1.8 & 35.3 & -11.1 & 79.1 & 75.0 & 0.7 & 0.3 \\
\hline Malaysia & 18 & 3 & - & 1.9 & - & 9860.0 & 74. & - & 0.5 & & - & 50.0 & 26.0 & 104.0 & 36.0 & 41.0 & 57.0 & 5 & 5.2 & 5.4 & 10.6 & 0.7 & & - & -19.0 & 59 & 69 & 0.5 & 0.4 \\
\hline Mauritius & 4 & 1 & - & & - & 9770.0 & 75.1 & - & & 0.7 & & & & & & & & 3 & 3 & 4.3 & 2.2 & 0.7 & & - & -26.0 & & 62 & 0.6 & 0.4 \\
\hline Mexico & 58 & 6 & Civil & 2.6 & - & 9040.0 & 64 & - & 0.6 & 0.6 & - & 69.0 & 30.0 & 81.0 & 82.0 & 24.0 & 97.0 & 3 & 3 & 4.1 & 2.4 & 0.7 & 0.3 & - & -27.4 & & & 0.4 & 0.4 \\
\hline Morocco & 2 & & & & & 2850.0 & 61.9 & & & 0.5 & & 53.0 & 46.0 & 70.0 & 68.0 & 14.0 & 25.0 & 3 & 3.0 & 3.9 & 1.7 & 0.5 & & & -33.9 & 63.5 & 66 & 0.4 & 0.4 \\
\hline Netherlan & 71 & 9 & Civil & 2.9 & 3.6 & 46640.0 & 76.2 & 0.7 & 0.4 & 0.9 & 58.0 & 14.0 & 80.0 & 38.0 & 53.0 & 67.0 & 68.0 & 5.2 & 5.6 & 5.7 & 211.9 & 0.9 & 13.8 & 18.8 & 9.3 & 75.5 & 79.9 & 0.7 & 0.4 \\
\hline New Zealand & 2 & - & Common & 1.0 & - & 38750.0 & 84.2 & 0.2 & 0.5 & . & 60.0 & 58.0 & 79.0 & 22.0 & 49.0 & 33 & 75.0 & 4.4 & 4.8 & 5.3 & 80.5 & 0.9 & 14.7 & 20.3 & -15.2 & & 77.6 & 0.8 & 0.3 \\
\hline Nigeria & 8 & 6 & - & & & 2450.0 & 58.5 & & 0.4 & 0.3 & & & & & & 13.0 & 84.0 & 2.9 & 2.5 & 3.9 & 0.0 & 0.5 & & & -33.1 & & $4 \varepsilon$ & 0.2 & 0.5 \\
\hline Norw & 32 & 2 & Civil & 2.3 & 3.3 & 82440.0 & 74.3 & 0.8 & 0.4 & 0.9 & 70.0 & 8.0 & 69.0 & 31.0 & 50.0 & 35.0 & 55.0 & 4.9 & 4.8 & 5.3 & 139.3 & 0.9 & 0.2 & 53.1 & 8.0 & & 9 & 0.8 & 0.3 \\
\hline Oman & 3 & - & - & & - & & 61.0 & - & & - & - & & & & & & - & 2.9 & 3.6 & 3.8 & 0.4 & 0.7 & - & - & -32.5 & 51.3 & 64.3 & 0.5 & 0.4 \\
\hline Pakistan & 5 & - & - & - & - & 1500.0 & 54.4 & - & 0.4 & 0.4 & - & 50.0 & 14.0 & 55.0 & 70.0 & 50.0 & 0.0 & 3.5 & 3.5 & 4.0 & 0.0 & 0.4 & - & - & -28.1 & 37.5 & 55.6 & 0.3 & 0.5 \\
\hline
\end{tabular}




\begin{tabular}{|c|c|c|c|c|c|c|c|c|c|c|c|c|c|c|c|c|c|c|c|c|c|c|c|c|c|c|c|c|c|}
\hline Panama & 2 & - & Civil & 1.7 & - & 12140.0 & 67.0 & - & - & 0.6 & - & 44.0 & 11.0 & 95.0 & 86.0 & - & - & 3.4 & 3.3 & 4.3 & 1.4 & 0.7 & - & - & -23.4 & 62.7 & 63.9 & 0.4 & 0.4 \\
\hline Paraguay & 1 & 1 & Civil & 1.8 & - & 4060.0 & 62.1 & - & & 0.5 & - & & & & & & & 2.7 & 2.6 & 3.8 & 0.0 & 0.6 & - & - & & 53.9 & 66.1 & 0.3 & 0.4 \\
\hline Peru & 37 & 4 & Civil & 2.2 & - & 5950.0 & 68.7 & - & 0.6 & 0.6 & - & 42.0 & 16.0 & 64.0 & 87.0 & 25.0 & 46.0 & 2.7 & 2.9 & 3.6 & 0.6 & 0.7 & - & - & -26.7 & 61.9 & 66.0 & 0.4 & 0.4 \\
\hline Philippines & 9 & 4 & & & - & 3580.0 & 65.0 & - & 0.6 & 0.6 & - & 64.0 & 32.0 & 94.0 & 44.0 & 27.0 & 42.0 & 3.5 & 3.5 & 4.5 & 0.4 & 0.6 & & & -29.6 & 57.7 & 64.3 & 0.3 & 0.5 \\
\hline Poland & 17 & & Civil & 2.4 & 2.6 & 12690.0 & 68.5 & & & 0.8 & - & 64.0 & 60.0 & 68.0 & 93.0 & 38.0 & 29.0 & 3.4 & 3.2 & 4.1 & 10.5 & 0.9 & 2.2 & 12.7 & -26.4 & 64.1 & 75.8 & 0.6 & 0.3 \\
\hline Portugal & 28 & 4 & Civil & 2.7 & 2.1 & 19880.0 & 63.4 & 0.7 & 0.5 & 0.8 & - & 31.0 & 27.0 & 63.0 & 104.0 & 28.0 & 33.0 & 3.8 & 4.2 & 4.6 & 15.4 & 0.8 & 6.2 & 18.8 & 2.3 & 71.9 & 75.6 & 0.6 & 0.3 \\
\hline Qatar & 11 & 1 & & & & & 72.6 & & & & - & & & & & & & 5.1 & 5.1 & 4.8 & 13.9 & 0.7 & & & -29.7 & 67.8 & 63.1 & 0.4 & 0.4 \\
\hline Romania & 2 & & Civil & & & 9480.0 & 69.4 & - & - & 0.7 & - & 42.0 & 30.0 & 90.0 & 90.0 & 52.0 & 20.0 & 2.8 & 3.1 & 3.7 & 3.9 & 0.8 & - & - & -18.0 & 64.8 & 74.1 & 0.5 & 0.4 \\
\hline Russia & 36 & 2 & Civil & 2.5 & 0.6 & 9720.0 & 58.2 & - & - & 0.7 & - & 36.0 & 39.0 & 93.0 & 95.0 & 81.0 & 20.0 & 3.5 & 3.9 & 4.2 & 7.8 & 0.8 & - & - & -32.4 & 63.8 & 68.9 & & 0.4 \\
\hline Saudi Arabia & 6 & . & & 1.1 & - & 21720.0 & 59.6 & - & - & & - & & & & & 36.0 & 52.0 & 3.6 & 3.7 & 4.2 & 8.9 & 0.8 & - & - & -37.1 & 57.5 & 62.7 & 0.5 & 0.4 \\
\hline Serbia & 5 & - & Civil & 2.2 & - & 5310.0 & 62.5 & - & - & 0.7 & - & 43.0 & 25.0 & 86.0 & 92.0 & 52.0 & 28.0 & 2.9 & 3.2 & 3.5 & 4.1 & 0.8 & - & - & -24.3 & 57.5 & 73.6 & & 0.4 \\
\hline Singapore & 35 & 5 & & & & 51880.0 & 88.8 & - & 0.5 & & 39.0 & 48.0 & 20.0 & 74.0 & 8.0 & 72.0 & 46.0 & 5.0 & 5.3 & 5.1 & 144.9 & 0.8 & - & & 0.8 & 64.2 & 69.0 & 0.8 & 0.4 \\
\hline Slovenia & 5 & - & Civil & 2.4 & 2.3 & 21620.0 & 64.8 & - & & 0.8 & 19.0 & 19.0 & 27.0 & 71.0 & 88.0 & 49.0 & 48.0 & 4.2 & 3.8 & 4.8 & 71.9 & 0.9 & - & 22.0 & -23.8 & 67.6 & 80.5 & & \\
\hline South Africa & 27 & 6 & - & 2.0 & 0.7 & 5490.0 & 63.0 & - & 0.5 & 0.4 & & 63.0 & 65.0 & 49.0 & 49.0 & 34.0 & 63.0 & 4.3 & 4.4 & 4.9 & 5.8 & 0.7 & - & & -12.6 & 44.7 & 61.2 & 0.4 & 0.4 \\
\hline South Korea & 28 & 7 & - & 2.2 & 2.6 & 27600.0 & 73.8 & - & 0.2 & 0.8 & 48.0 & 39.0 & 18.0 & 60.0 & 85.0 & 100.0 & 29.0 & 4.4 & 4.4 & 4.7 & 249.5 & 0.9 & - & 10.1 & -12.1 & 62.3 & 75.5 & - & . \\
\hline Spain & 80 & 16 & Civil & 2.4 & 2.2 & 27600.0 & 65.1 & 0.6 & 0.5 & 0.8 & 35.0 & 42.0 & 51.0 & 57.0 & 86.0 & 48.0 & 44.0 & 3.5 & 3.5 & 4.3 & 39.0 & 0.8 & 3.5 & 17.0 & 4.2 & 78.4 & 76.8 & 0.6 & 0.3 \\
\hline Sri Lanka & 16 & 4 & & & & 3780.0 & 57.8 & & 0.6 & 0.7 & & & & & & & & 3.7 & 3.6 & 4.1 & 0.7 & 0.8 & & & -24.4 & 60.6 & 65.9 & 0.4 & 0.5 \\
\hline Sweden & 120 & 13 & Civil & 2.5 & 3.1 & 54590.0 & 76.3 & 0.7 & 0.3 & 0.9 & 60.0 & 5.0 & 71.0 & 31.0 & 29.0 & 53.0 & 78.0 & 5.6 & 5.2 & 5.8 & 317.9 & 0.9 & 10.3 & 67.4 & 19.5 & 80.5 & 85.6 & 0.7 & 0.3 \\
\hline Swizzerland & 69 & 7 & Civil & 2.1 & 3.3 & 81240.0 & 81.7 & 0.5 & 0.4 & 0.9 & & 70.0 & 68.0 & 26.0 & 56.0 & 74.0 & 66.0 & 6.1 & 5.8 & 6.2 & 300.1 & 0.9 & & 16.6 & 20.6 & 87.4 & 81.2 & 0.7 & 0.3 \\
\hline Taiwan & 253 & 9 & & & & & 76.6 & 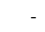 & 0.2 & & - & 45.0 & 17.0 & 58.0 & 69.0 & 93.0 & 49.0 & 5.2 & 4.8 & 5.1 & & & - & - & -22.0 & 72.8 & & & \\
\hline Thailand & 64 & 18 & Civil & 2.2 & & 5640.0 & 67.1 & - & 0.5 & 0.6 & & 34.0 & 20.0 & 64.0 & 64.0 & 32.0 & 45.0 & 3.6 & 3.9 & 4.1 & 1.5 & 0.6 & - & - & -17.8 & 49.9 & 69.5 & 0.5 & 0.4 \\
\hline Turkey & 67 & 7 & Civil & 2.3 & 1.8 & 11230.0 & 65.4 & - & 0.6 & 0.6 & 21.0 & 45.0 & 37.0 & 66.0 & 85.0 & 46.0 & 49.0 & 3.3 & 3.5 & 4.1 & 10.9 & 0.7 & 11.5 & - & -27.8 & 53.0 & 68.5 & 0.5 & 0.3 \\
\hline Ukraine & 1 & - & Civil & & - & 2310.0 & 51.9 & - & & 0.7 & & - & - & - & - & 86.0 & 14.0 & 3.2 & 3.4 & 4.3 & 3.6 & 0.8 & - & - & -31.7 & 52.9 & 72.7 & & \\
\hline United Arab Emirates & 22 & 5 & & & & 40480.0 & 77.6 & & & & & & & & & & & 4.5 & 4.5 & 5.4 & 9.4 & 0.7 & & & -24.2 & 58.9 & 66.0 & 0.6 & 0.4 \\
\hline United Kingdom & 44 & 13 & Common & 1.6 & 3.3 & 42330.0 & 78.0 & 0.1 & 0.2 & 0.8 & 48.0 & 66.0 & 89.0 & 35.0 & 35.0 & 51.0 & 69.0 & 5.1 & 5.4 & 5.5 & 99.1 & 0.9 & 24.5 & 26.1 & 9.6 & 79.9 & 78.3 & 0.7 & 0.3 \\
\hline United States & 230 & 49 & Common & 1.2 & 3.2 & 56810.0 & 75.7 & 0.0 & 0.2 & 0.8 & 62.0 & 62.0 & 91.0 & 40.0 & 46.0 & 26.0 & 68.0 & 5.9 & 5.7 & 6.0 & 176.5 & 0.9 & 19.1 & & -11.0 & 71.2 & 72.4 & 0.7 & 0.3 \\
\hline Uruguay & 1 & & Civil & 2.0 & & 15230.0 & 69.2 & & & 0.7 & & 38.0 & 36.0 & 61.0 & 100.0 & 26.0 & 53.0 & 2.9 & 3.3 & 3.7 & 2.2 & 0.7 & - & - & -27.0 & 64.7 & 71.0 & 0.5 & 0.4 \\
\hline Venezuela & 4 & - & Civil & 3.5 & - & & 25.2 & - & 0.5 & 0.6 & - & 73.0 & 12.0 & 81.0 & 76.0 & 16.0 & 100.0 & 2.5 & 3.0 & 3.6 & 0.2 & 0.7 & - & - & -35.4 & 63.9 & 65.8 & 0.2 & 0.3 \\
\hline Vietnam & 8 & 1 & Civil & & - & 2100.0 & 53.1 & - & - & 0.6 & & 40.0 & 20.0 & 70.0 & 30.0 & 57.0 & 35.0 & 3.6 & 3.5 & 4.0 & 0.2 & 0.6 & - & - & -25.6 & 47.0 & 67.9 & 0.4 & 0.5 \\
\hline Zimbabwe & 2 & 1 & & - & - & 890.0 & 44.0 & - & 0.6 & 0.4 & - & & & & & 15.0 & 28.0 & 2.5 & 2.5 & 3.2 & 0.1 & 0.5 & - & - & & 43.4 & 56.1 & 0.2 & 0.5 \\
\hline
\end{tabular}

Table A: Description of the study variables, by country.

$N(T o t)=$ total number of organizations; $N(S D G)=$ total number of $S D G$ reporting organizations. 